\title{
Environmental Participation and Environmental Motivation
}

\author{
Benno Torgler. ${ }^{* a, b, d}$, María A.García-Valiñas ${ }^{c}$ and Alison \\ Macintyre
}

Working/Discussion Paper \# 238

October 2008

Abstract:

We explore whether environmental motivation affects environmental behavior by focusing on volunteering. The paper first introduces a theoretical model of volunteering in environmental organizations. In a next step, it tests the hypothesis working a large micro data set covering 32 countries from both Western and Eastern Europe using several different proxies to measure environmental motivation. As a robustness test we also explore the relationship at the macro level extending the number of countries investigated. Our results indicate a strong positive relationship between environmental motivation and individuals' voluntary engagement in environmental organizations.

JEL Classifications: D11, H41, H26, H73, D64

Keywords: environmental participation, environmental motivation, environmental morale, pro-environmental attitudes, social capital

\footnotetext{
*Corresponding author (benno.torgler@qut.edu.au). For helpful comments and suggestions thanks are due to Markus Schaffner and Arik Levinson.
} 


\section{INTRODUCTION}

Why is it that a growing number of studies are devoted to examining individual environmental preferences, proposing that individuals' environmental morale or attitudes could help to reduce environmental degradation or the problems of free riding associated with public goods (see, for example Frey and Stutzer, 2006)? One motivation for such a suggestion is that control and deterrence models predict a far lower level of compliance than that actually observed. In many countries, the level of government control is too low to explain the high degree of environmental compliance.

However, there are few studies exploring empirically whether such proenvironmental attitudes exert a positive effect on either environmental behavior or involvement in environmental organizations. The presence of such norms or environmental motivation influencing the willingness to protect the environment is especially useful in situations where it is extraordinarily expensive to arrange a regulatory enforcement regime. A desirable and positive side effect of voluntary compliance is that it lowers the cost of government operations aimed at ensuring public good provision (Slemrod 2002).

We focus on the individuals’ participation in environmental organizations because it is a cooperative behavior that can improve social capital, especially the network component ${ }^{1}$. Recent studies in the area of ecological economics have shown that social capital indeed influences transaction costs and can also have some bearing on the effectiveness of public environmental policies (see Torgler and Garcia-Valiñas, 2007).

\footnotetext{
${ }^{1}$ See Grootaert and van Bastalaer (2002, p.41-66)
} 
These results suggest that "environmental conflicts can be resolved by making collective choices that are implemented by establishing, changing or reaffirming governance institutions” (Paavola and Adger, 2005, p. 364). The adaptive capability of societies is strongly linked to their ability to act collectively (Adger, 2003), thus the existence of social capital is important when dealing with new environmental scenarios, such as the threat of climate change, or for coping with the impact of environmental disasters, such as droughts or floods. Katz (2000) showed that social capital is related to the ability to address several market failures regarding common property natural resources.

The strength of this paper lies in exploring the impact of environmental motivation on environmental behavior. We focus on individuals' voluntary engagement in environmental organizations and test its impact with the use of both a large micro data set covering 32 European countries and a macro data set that also works with a large set of 52 countries. Such breadth and depth of data allows exploration of the different channels through which individuals express their environmental motivation via proenvironmental attitudes, and we capitalize on this opportunity by exploring two variables that measure voluntary environmental participation (i.e. membership and voluntary work).

The outline of the paper is as follows. Section 2 of the paper first discusses the theoretical background and proposes a model of volunteering. Section 3 introduces the data set and the key variables. The empirical findings are presented in Section 4 and some concluding remarks are offered in Section 5. 


\section{THEORETICAL CONSIDERATIONS}

What is the meaning of 'pro-environmental behavior'? Kollmuss and Agyeman (2002) define it as actions taken by an individual in consciously seeking to minimize the negative impact of human activities on the environment and Jensen (2002) refers to those personal actions that are directly related to environmental improvements. Some daily activities, such as minimizing resource and energy consumption, reducing and recycling waste, or using public transport are private actions which contribute to the preservation of nature.

In the same way, participation in environmental organizations can be seen as a kind of pro-environmental behavior and is highly relevant in ensuring the efficacy of environmental policies which require behavioral changes. As Handy (2001, p.648) pointed out, "much of the initial impetus towards change for protecting environmental quality came from concerned individuals who have often come together and formed voluntary non-profit associations to collectively address environmental concerns. Their persistent lobbying and advocating for environmental protection has changed public sentiment, thereby convincing government and businesses to pay attention to their demands. (...) Nevertheless, many environmental nonprofit organisations continue to play an important role in advocating a better environmental quality”.

Civil engagement in voluntary organizations is gaining increased attention from researchers; nonetheless the causes of environmental participation are still relatively unknown. The benefit of participation in voluntary activities is the creation of social output that would per se require paid resources (Freeman, 1997). Pretty and Ward (2001) 
showed that the creation of active pro-environmental groups was significant for solving certain local environmental problems ${ }^{2}$. Our study will not only explore the gender, age and parental effect, but will also show who is likely to participate and whose priorities and values are best promoted by voluntary work in environmental organizations. However, to date only a few studies have analyzed the factors impacting on the participation in environmental organizations (Mohai, 1992; Thompson and Barton, 1994; Martinez and McMullin, 2004). The advantage of focusing on direct participation in environmental organizations is that individuals' behavior can be measured. Moreover, it builds a bridge between the social capital literature that focuses on volunteering and the environmental literature on pro-environmental preferences.

The relevance of looking beyond the neoclassical approach in understanding seemingly non-rational behavior is demonstrated in the tax compliance literature and the analyses of tax paying behavior. In seeking to explain the reasons why citizens comply with tax regulations given that the probability of being audited is extremely low, it is clear that deterrence mechanisms alone cannot explain the level of observed compliance in this regard (Torgler 2007). Similarly, the level of formal deterrence is too low to explain why, for example, people do not litter more often. Invoking the power of social norms helps to resolve such a puzzle, but further empirical evidence is required to determine whether environmental attitudes affect environmental actions. We note that previous literature has shown how values and attitudes can affect individual behavior in more general sense (Ajzen and Fishbein, 1980; Lewis, 1982). Thus, it is useful to explore whether the decision to participate in environmental organizations is driven by a set of

\footnotetext{
${ }^{2}$ Those authors analyzed some environmental organizations in rural communities. They found an evolution from reactive-dependence groups (static and created exclusively in reaction to a threat or a crisis), towards awareness-interdependence groups (more dynamic and interactive).
} 
attitudes and norms. Our theoretical model is strongly influenced by previous studies on altruism (Andreoni, 1990) and moral motivation ${ }^{3}$ in a public good environment (Brekke et al. 2003).

When considered from an economic perspective, environmental participation "exemplifies an individual's voluntary effort to provide an environmental public good" (Clark et al. 2003, p. 238). An economic analysis also prompts the question: why do people take actions (incurring private costs) that result in collective benefits? While the traditional theoretical models predict a free-rider effect in the private provision of public goods, in practice we find clear evidence to the contrary (Andreoni, 1988; Piliavin and Charng, 1990). Andreoni (1990, p. 465) developed an important model of impure altruism as a means of understanding donations to public goods. He assumes an economy with only one private good and one public good. The individual utility donation function depends on the consumption of a private good $\left(x_{i}\right)$, the total amount of a public good $(G)$, and the individual's gift to the public good $\left(g_{i}\right)$. Thus, $U i=U\left(x_{i}, G, g_{i}\right)$. This allows the author to differentiate two cases, namely a purely altruistic situation $U\left(x_{i}, G_{i}\right)$ when the individual cares nothing for the private gift, and $U\left(x_{i}, g_{i}\right)$ when the individual is motivated to give only by a "warm-glow" outcome (purely egoistic). The cases in between are defined as an impurely altruistic behavior. However, he acknowledges that there are important alternative approaches to such an impure altruism model, namely moral or

\footnotetext{
${ }^{3}$ The literature has identified a "free-ride" effect, in order to explain why people do not participate actively in voluntary organizations. Thus, if an individual perceives that he/she can benefit from any successful outcome of collective action, whether or not they contributed to achieve it, then he/she can decide not to contribute actively at all. According to Lubell et al. (2006, p. 150), when collective action is analyzed, is necessary to "incorporate the logic of free riding by acknowledging that the contribution of a single individual only raises the probability of successfully providing a public good by small amount. From this perspective, how individuals perceive their own personal influence on collective outcomes is the critical value”. So, the free-rider effect is a significant and additional argument that clarifies why people can fail to participate actively in environmental groups.
} 
group-interested behavior. In line with this suggestion, Brekke et al. (2003) implement moral motivation in their model by working with a social welfare function to determine the morally ideal effort, where individuals share a utilitarian moral philosophy. For simplicity, they assume that the labor supply and the income are exogenously fixed. In a next step, individuals maximize their utility in a benefit-cost environment, trading the benefits of maintaining a self-image as socially responsible individuals against the costs. The desire to improve self-image induces an improved effort towards upholding beliefs that are perceived to be morally right.

Keeping in mind the theoretical work outlined above, we examine the motivation for environmental participation by developing a model of volunteering. We assume that individual's utility function is given by

$$
U_{i}=U\left(x_{i}, l_{i}, G, \lambda_{i}\right)
$$

where $x_{i}$ is individual $i$ 's consumption of private goods, $l_{i}$ represents leisure, $G$ is the public good of increasing environmental quality, and $\lambda_{i}$ the utility from participating voluntarily in an environmental organization.

Voluntary work is time consuming and subject to opportunity costs. Thus, $v_{i}$ represents the hours spent for voluntary work in an environmental organization. Individuals' consumption can therefore be written as an income constraint, defined by the product of the wage rate $w$ and the working hours $T-l_{i}-v_{i} \geq 0$, where $T$ is the time constraint (available time): 


$$
x_{i}=w_{i}\left(T-l_{i}-v_{i}\right)
$$

The total amount of public good (environmental quality) depends on the public provision $G_{p}$ and private provision $\sum_{i} g_{i}$, assuming identical individuals $N$ :

$$
G=G_{p}+\sum_{i} g_{i}
$$

where

$$
g_{i}=\alpha v_{i}
$$

is individual i's production function that depends on the level of voluntary participation in an environmental organization and an efficiency parameter $\alpha$. Since we have identical individuals $\sum_{i} g_{i}$ is equal to $N g_{i}$. Therefore, we can write:

$$
G=G_{p}+N \alpha v_{i}
$$

The utility from participating in a voluntary environmental organization $\left(\lambda_{i}\right)$ has the following form: 


$$
\lambda_{i}=m_{i} v_{i}-\left(m_{i}-v_{i}\right)^{2}
$$

where $m_{i}$ is a factor that measures an individual's motivation to contribute to the environment $\left(m_{i} \geq 0\right)$. It measures what the individual believes to be the morally ideal environmental involvement. Thus, participating in voluntary organizations is correlated with individuals' motivation towards contribution and this enhances an individual's utility function (see first term). On the other hand, if the participation in voluntary organizations is l-ower than the morally ideal environmental involvement $\left(v_{i}<m_{i}\right)$, individuals also experience moral or psychic costs (see second term). This induces a feeling of guilt and shame.

We also assume that the utility function is additively separable in $x_{i}, l_{i}, G$, and $\lambda_{i}$. The utility function thus becomes:

$$
U_{i}=x_{i}+l_{i}+G+\lambda_{i}
$$

Considering (2) to (6) leads to the following utility function:

$$
U_{i}=w_{i}\left(T-l_{i}-v_{i}\right)+l_{i}+\left(G_{p}+N \alpha v_{i}\right)+m_{i} v_{i}-\left(m_{i}-v_{i}\right)^{2}
$$


An individual maximizes utility (8) subject to her voluntary involvement in an environmental organization $\left(v_{i}\right)$. Setting the first order condition $U_{i}^{\prime}=\frac{\partial U_{i}}{\partial v_{i}}$ equal to 0 leads to the following condition for the optimal effort engagement:

$$
v_{i}=\frac{-w_{i}+N \alpha+3 m_{i}}{2}
$$

Eq. (9) suggests that environmental participation will increase with an increase in individual's motivation to contribute. Thus, we can develop the following main hypothesis:

Hypothesis 1: A higher level of environmental motivation due to higher environmental moral standards leads to a stronger voluntary involvement in environmental organizations.

Moreover, Eq. (9) also indicates that an increase in the wage rate changes the allocation of time. An increase leads to a decline of voluntary work in environmental organizations. However, such a negative effect is reduced with a higher level of efficiency in the contribution of the private provision of the public good, $\alpha$ multiplied by the number of individuals in the society. It should be noted that we have implemented a consumer model. One may argue that individuals are also volunteering to accumulate human capital with the intention of increasing future income through the acquisition of certain types of skills and through creating and developing networks that enhance their human capital 
(Hackl et al., 2007). This would require the use of an investment model with a dynamic structure. However, we believe that our consumer model is useful and appropriate when exploring moral values.

\section{DATA}

We use two variables that measure involvement in a voluntary environmental organization, namely membership and doing unpaid work:

Please look carefully at the following list of voluntary organizations and activities and say which, if any, are you currently doing unpaid voluntary work for: conservation, the environment, ecology, animal rights (1=yes, 0 otherwise).

Please look carefully at the following list of voluntary organizations and activities and say which, if any, do you belong: conservation, the environment, ecology, animal rights ( $1=$ mentioned, $0=$ not mentioned $)$.

To ensure the robustness of results, we use several dependent variables that can be seen as a proxy $m$, namely the motivation to contribute to the environment. The first two variables measure $m$ in the following way:

I would give part of my income if I were certain that the money would be used to prevent environmental pollution ( $0=$ strongly disagree, $3=$ strongly agree) 
I would agree to an increase in taxes if the extra money were used to prevent environmental pollution ( $0=$ strongly disagree, $3=$ strongly agree $)$

Although we are not conducting a contingent valuation study (CV), these two questions offer the chance to explore our parameter $m$. However, the question is not free of problems and can be criticized in several ways. The statement is relatively vague: "environmental pollution" is not clearly specified, and neither is the level of improvement. Similarly, the proportion of income to be spent and the degree of tax increase are not clarified. Therefore the respondents are not aware of how much they would hypothetically have to contribute ${ }^{4}$. The consequences of taxation are not mentioned and no information is provided regarding the extent to which income tax, value added tax or other taxes are supposed to increase. Thus, it is not clear who will bear the highest tax burden. Such unspecified questions regarding the payment schemes will increase the variance in responses, but on the other hand, may influence the willingness to contribute (Witzke and Urfei, 2001). Nevertheless, despite these possible shortcomings, an unspecified statement still helps to measure moral values and to reduce strategic behavior via influencing the quantity or quality of environmental goods. Providing a more concrete scenario could encourage respondents to intentionally indicate a false willingness to contribute to ensure that the outcome of the study matches their own preferences (Hidano et al., 2005). When neither specific goods nor quantitative values are used, the attributes of the environmental goods in question do not have to be

\footnotetext{
${ }^{4}$ It has been shown that the preferences to protect the environment (regarding causes and consequences of environmental damages) depend on the level of information included in the questionnaire (Bulte et al., 2005).
} 
thoroughly explained to ensure that respondents understand the proposition and respond with the appropriate willingness to sacrifice income and accept an increase in taxes ${ }^{5}$.

In a next step we will explore a variable that measures environmental attitudes, but takes into account the possibility that people may have an incentive to free-ride (profit without incurring costs). We would predict that such a variable would lead to contradictory results (compared to the previous two variables):

The Government has to reduce environmental pollution but it should not cost me any money $(0=$ strongly disagree, $3=$ strongly agree $)$

Our multivariate analysis includes a vector of control variables, which are explained in the Appendix. Previous research in environmental economics and social norms demonstrates the relevance of considering such socio-demographic factors, formal and informal education and participation in an environmental organization (see Torgler and Garcia-Valiñas, 2007; Torgler, 2007). We also differentiate between the two regions of Europe (i.e. Western and Eastern Europe) to account for effects of the reform process in the transition countries. The rapid collapse of institutional structures in Eastern European countries produced a vacuum in many, if not all, of these countries. This led to large social costs, especially in terms of worsening income inequalities, increasing poverty and poor institutional conditions resulting from uncertainty and high transaction costs. Torgler (2003) and Alm et al. (2006) show that such circumstances have an impact on social norms.

\footnotetext{
${ }^{5}$ For a detailed discussion regarding possible survey biases see Carson and Mitchell (1995).
} 


\section{EMPIRICAL RESULTS}

The following micro level analysis uses data provided by the European Values Survey (EVS) 1999/2000, which is a European-wide investigation of socio-cultural and political change. The survey collects data on the basic values and beliefs of people throughout Europe. The EVS was first carried out from 1981 to 1983, then in 1990 to 1991 and again in 1999 through 2001, with an increasing number of countries participating over time. The methodological approach is explained in detail in the European Values Survey (1999) source book, which provides information on response rates, the stages of sampling procedures, the translation of the questionnaire, and field work, along with measures of coding consistency, reliability of data, and data checks. All country surveys are conducted by experienced professional survey organizations, with the exception of Greece. Interviews are face-to-face and those interviewed are adult citizens aged 18 years and older. Tilburg University coordinates the project and provides the guidelines to guarantee the use of standardized information in the surveys and the national representativeness of the data. To avoid framing biases, the questions are asked in a prescribed order. The response rates vary from country to country with an average response rate of around 60 percent.

Because EVS poses an identical set of questions to individuals in various European countries, the survey provides a unique opportunity to empirically examine our hypotheses. We are able to employ a large data set considering 32 representative national samples. EVS has been designed as a wide-ranging survey, thereby reducing the danger of framing effects when compared with many other surveys that focus entirely on 
environmental questions. A further advantage of using this extensive data set is the ability to explore a large number of dependent variables.

In the macro analysis we not only explore the EVS but also the World Values Survey (WVS) using the same wave. EVS can be seen as a subpart of the WVS, although one should note that the questions are not always fully identical. For example, in the empirical micro analysis we are also going to use .data that has not been collected in the WVS.

Economists are increasingly using survey data in areas of research such as those dealing with social capital, corruption, happiness and tax compliance. These literatures explore the causes of attitudes (see, e.g., Frey and Stutzer, 2002; Brewer and Steenbergen, 2002; Uslaner, 2004; Brewer et al., 2004; and Chang and Chu, 2006 and Torgler, 2008).

In general, a probit estimation is appropriate when working with information such as our two dependent variables that measure participation in environmental organizations. We calculate the marginal effects to measure the quantitative effect of a variable, because the equation is nonlinear. Marginal effects indicate the change in the probability of individuals having a specific level of environmental preferences when the independent variable increases by one unit. Weighted estimates are conducted to ensure that the samples correspond to the national distribution. ${ }^{6}$ Furthermore, answers such as 'don't know' are eliminated in all estimations, as are any missing values.

Table 1 presents the findings regarding membership in an environmental organization. In the first three specifications we explore our key environmental motivation variables $m$ separately and the fourth includes all the three variables in the

\footnotetext{
${ }^{6}$ The weighting variable is provided by the EVS.
} 
specification. The results from the first three specifications indicate that all the $m$ proxies are statistically significant. The first two have a positive impact, and the third has a negative impact. Thus, hypothesis 1 cannot be rejected. A higher level of environmental motivation due to higher moral standards induces voluntary involvement in environmental organizations. The negative coefficient in specification (3) is consistent with our prediction as it measures individuals' interest in free-riding. A higher willingness to free-ride is negatively correlated with environmental engagement. The variable WILLINGESS TO GIVE INCOME has the strongest effect. An increase in the scale by one unit raises the probability of participating in an environmental organization by 2.5 percentage points. The importance of this variable is also visible once you include all three variables in the regression. The coefficient is still statistically significant at the $1 \%$ level with a marginal effect of 1.9 percentage points. On the other hand, the coefficient for the variable WILLINGNESS TO INCREASE TAXES is only statistically significant at the $10 \%$ level, and also shows a decrease in the marginal effects. Overall, these first results indicate that environmental motivation matters.

Looking at the control variables we can see that women are more likely to be members of environmental organizations. Age is also positively correlated with being a member. Overall, the age group AGE 50-59 shows the strongest level of environmental participation (largest marginal effects). Having a child is negatively correlated with environmental participation, possibly because time restrictions may act as a barrier to being involved in environmental organizations. Education and political interest, measured as political discussion, have a positive impact on the probability of being a member in an environmental organization. The time restriction argument may also be invoked when 
focusing on the marital status. Those who have never before been married, and those who are separated exhibit the highest probability of participating in environmental organizations. Moreover, when taking employment status into account, we observe that part time employees are more likely to be members. There is also the tendency for selfemployed individuals to be more active in environmental organizations, probably because of the opportunity to improve their networks. On the other hand, the time restriction argument fails when it comes to the unemployed and retired, as they are less likely to be members than are full-time employees. Finally, we also observe that people in Western Europe are more likely to engage with environmental organizations through membership. The marginal effects are quite large (more than 4 percentage points).

In Table 2 we explore a second aspect, namely doing unpaid work for environmental organizations. The results are quite similar. All the proxies for $m$ in specification (5) to (7) are statistically significant. The strongest effects are again observable for the variable WILLINGNESS TO GIVE INCOME. However, it should be noted that compared to Table 1 we find lower quantitative effects. Specification (8) also shows that the coefficient for the variable CONTRIBUTE AT NO COSTS is no longer statistically significant.

Looking at the control variables we find that contrary to the results on membership, there is now a negative correlation between environmental participation and being a woman. Thus, women are more likely to be a member in an environmental organization, but are less likely to do unpaid work. However, it can be argued that women might be more active in community-based and neighborhood organizations which address local environmental issues, while men are more likely to participate in formal 
environmental organizations. Our survey question captures more of the latter than the former - for this reason, our results may not actually conflict with findings to the contrary. Moreover, it should be noted that women (particularly younger women) would face other restrictions on their ability to participate in voluntary organizations, as they are often more heavily involved in time intensive household activities.

The age effect is now less visible, but we still observe that the AGE group 50-59 has the strongest probability of doing unpaid work and that both education and political interest have a significant and positive impact on environmental engagement. Moreover, we also observe that the "never married” individuals are the most active in environmental organizations. On the other hand, the parental effect is now less obvious and it appears that only retired people are significantly less willing than the full time-employed individuals to be active in environmental organizations through unpaid work. Finally we again observe that Western European citizens are more likely to be environmentally engaged. However, the effect is not as strong as for membership and the coefficient is no longer statistically significant in all specifications.

In the next two tables we extend the previous regression by including individuals’ economic situation with two dummy variables. It should be noted that the number of observations in Table 3 and 4 strongly decreased after controlling for individuals' economic situation. The results indicate that a higher level of economic status leads to a higher probability of being a member and doing unpaid work in environmental organizations. It seems that wealthier citizens have a higher demand for a clean environment and less environmental damages and thus a stronger incentive to actively contribute to the environment by participating in a voluntary organization. Thus, such a 
result is not consistent with our Eq. (9). However, it should be noted that the economic situation variable may not only cover the current wage but also the accumulated wealth over time. Nevertheless, we observe that the results obtained previously remain robust.

Table 5 explores the potential endogeneity problems. One can argue that being involved in an environmental organization enhances pro-social environmental attitudes. To control for such a problem, we will use an instrumental approach to check the robustness of the results. A suitable instrument must be contemporaneously uncorrelated with the error term but must be highly correlated with membership in a voluntary environmental organization. Our instrument (an index of perceived level of social noncompliance with well-known social rules ${ }^{7}$ ) satisfies these conditions.

For simplicity, we only report the results on membership involvement in Table 5. In previous studies we have seen that the perceived level of compliance affects individuals' intrinsic motivation to contribute and cooperate (Frey and Torgler 2008, Torgler, Frey and Wilson 2008, Dong, Dulleck and Torgler 2008). The extent to which others comply with social rules systematically influences the individual willingness and motivation to contribute. Additionally, Owen and Videras (2006) found a positive and significant relationship between civic cooperation and/or allowing free-ride behaviors and environmental attitudes and intentions. They concluded that civic cooperation was a key factor to improving pro-environmental attitudes, especially in low income countries.

\footnotetext{
${ }^{7}$ Aggregated index of the following questions: According to you, how many of your compatriots do the following: Claming state benefits to which they are not entitled; Driving under the influence of alcohol; Speeding over the limit in built-up areas (each scale from $4=$ almost all to $1=$ almost none).
} 
The table reports the results of two-stage least squares (2SLS) estimations together with the first stage regressions. The results indicate that attitudes have a strong and significant impact on environmental involvement. In addition, Table 5 also shows that the instruments and the $F$-tests for the instrument exclusion set in the first-stage regression are statistically significant. There is a negative correlation between our environmental motivation variables and the perceived level of dishonest behavior. We also report the Anderson canonical correlations LR test for the relevance of the instruments, checking the relevance of the excluded instruments. A rejection of the null hypothesis indicates that the model is identified and that the instruments are relevant (see Hall et al., 1996). Moreover, we show results of the Anderson-Rubin test indicating that the endogenous variables are jointly statistically significant. Table 5 reports that in all cases the Anderson canonical correlations LR test shows rejection of the null hypothesis, which indicates that the models are identified and that the instruments are relevant. The Anderson-Rubin test is also statistically significant and has the advantage of being robust to the presence of weak instruments.

Finally, we test in Table 6 and 7 whether the impact of environmental motivation on environmental involvement is driven by a subset of countries and present the results for the coefficients for environmental attitudes in both tables using the specifications in the first two tables (without controlling for the economic situation). Each table is a summary of 96 regressions conducted within 32 countries. Table 6 focuses on membership participation, while Table 7 explores unpaid work as a dependent variable. In general we observe differences between the countries. Table 6 shows that the coefficient of the variable WILLINGNESS TO GIVE INCOME is statistically significant 
in 25 out of 32 cases, and the strongest effect is observed for the Netherlands. An increase in the WILLINGNESS TO GIVE INCOME by one unit increases the probability of being a member in an environmental organization by almost 10 percentage points. A strong quantitative effect is also observed in Austria, Belgium, Denmark and Greece, however the effects are generally lower among Eastern European countries. We find a similar result for the variable WILLIGNESS TO INCREASE TAXES. The coefficient is statistically significant in 24 out 32 cases. The strongest effect can also be found in the Netherlands (9.1 percentage points), followed by Denmark (4.4 percentage points) and Greece (3.4 percentage points). The results are less strong when focusing on willingness to free-ride. However, here we also observe the strongest negative impact for the Netherlands (8.9 percentage points), followed by Denmark (4.2 percentage points) and Belgium (4.2 percentage points). Looking at Table 7 and therefore at unpaid work we find that the relationship is less strong when using unpaid work instead of membership participation as a dependent variable. Thus, environmental motivation helps to substantially increase the number of memberships, but is less strong when individuals are required to do unpaid work for environmental organizations. The coefficient for the variable WILLIGNESS TO GIVE INCOME is now only statistically significant in 18 out 32 regressions. The quantitative effects are also substantially smaller. Greece reports the strongest effect with a marginal effect of 3.5 percentage points. Moreover, it should be noted that the same picture can be found for the other two motivational questions. 
Table 1: Determinants of Being A Member in Environmental Organizations

\begin{tabular}{|c|c|c|c|c|c|c|c|c|c|c|c|c|}
\hline & \multicolumn{12}{|c|}{ WEIGHTED PROBIT } \\
\hline & \multicolumn{3}{|c|}{ (1) } & \multicolumn{3}{|c|}{ (2) } & \multicolumn{3}{|c|}{ (3) } & \multicolumn{3}{|c|}{ (4) } \\
\hline & Coeff. & z-Stat. & Marg. & Coeff. & z-Stat. & Marg. & Coeff. & z-Stat. & Marg. & Coeff. & z-Stat. & Marg. \\
\hline $\begin{array}{l}\text { Environmental Motivation (m) } \\
\text { WILLINGNESS TO GIVE } \\
\text { INCOME } \\
\text { WILLINGNESS TO } \\
\text { INCREASE TAXES } \\
\text { CONTRIBUTE AT NO } \\
\text { COSTS } \\
\text { Gender }\end{array}$ & $0.313^{* * *}$ & 19.07 & 0.025 & $0.223 * * *$ & 14.81 & 0.019 & $-0.246 * * *$ & -17.43 & -0.020 & $\begin{array}{l}0.250 * * * \\
0.032 * \\
-0.177^{* * *}\end{array}$ & $\begin{array}{l}11.97 \\
1.70 \\
-11.79\end{array}$ & $\begin{array}{r}0.019 \\
0.002 \\
-0.014\end{array}$ \\
\hline $\begin{array}{l}\text { FEMALE } \\
\text { Age }\end{array}$ & $0.054 * *$ & 1.97 & 0.004 & $0.067 * *$ & 2.47 & 0.006 & $0.059 * *$ & 2.15 & 0.005 & $0.056 * *$ & 1.99 & 0.004 \\
\hline AGE 30-39 & 0.056 & 1.22 & 0.004 & 0.048 & 1.07 & 0.004 & 0.065 & 1.44 & 0.005 & 0.056 & 1.19 & 0.004 \\
\hline AGE 40-49 & $0.115^{* *}$ & 2.38 & 0.010 & $0.087^{*}$ & 1.82 & 0.008 & $0.110^{* *}$ & 2.28 & 0.010 & $0.112^{* *}$ & 2.25 & 0.009 \\
\hline AGE 50-59 & $0.237 * * *$ & 4.65 & 0.022 & $0.216 * * *$ & 4.31 & 0.021 & $0.251^{* * *}$ & 4.93 & 0.024 & $0.243 * * *$ & 4.62 & 0.022 \\
\hline AGE 60-69 & $0.189 * * *$ & 2.97 & 0.017 & $0.175^{* * *}$ & 2.77 & 0.016 & $0.212 * * *$ & 3.32 & 0.020 & $0.198 * * *$ & 3.02 & 0.018 \\
\hline $\begin{array}{l}\text { AGE } 70+ \\
\text { Parental Effect }\end{array}$ & $0.238 * * *$ & 3.23 & 0.022 & $0.198 * * *$ & 2.68 & 0.019 & $0.213 * * *$ & 2.89 & 0.020 & $0.227 * * *$ & 2.96 & 0.021 \\
\hline $\begin{array}{l}\text { CHILD } \\
\text { Formal and Informal } \\
\text { Educ. }\end{array}$ & $-0.104 *$ & -1.90 & -0.008 & $-0.120 * *$ & -2.19 & -0.009 & $-0.117 * *$ & -2.15 & -0.009 & $-0.108 *$ & -1.91 & -0.008 \\
\hline EDUCATION & $0.025 * * *$ & 12.02 & 0.002 & $0.025 * * *$ & 12.40 & 0.002 & $0.025 * * *$ & 12.18 & 0.002 & $0.022 * * *$ & 10.24 & 0.002 \\
\hline $\begin{array}{l}\text { POLITICAL DISCUSSION } \\
\text { Marital Status }\end{array}$ & $0.142^{* * *}$ & 7.01 & 0.011 & $0.151^{* * *}$ & 7.53 & 0.013 & $0.134 * * *$ & 6.64 & 0.011 & $0.114^{* * *}$ & 5.45 & 0.009 \\
\hline WIDOWED & $-0.103 *$ & -1.69 & -0.007 & $-0.159 * * *$ & -2.60 & -0.012 & $-0.143^{* *}$ & -2.37 & -0.011 & $-0.133 * *$ & -2.08 & -0.009 \\
\hline DIVORCED & -0.062 & -1.25 & -0.005 & -0.065 & -1.31 & -0.005 & -0.072 & -1.44 & -0.006 & -0.062 & -1.20 & -0.005 \\
\hline SEPARATED & 0.010 & 0.10 & 0.001 & 0.001 & 0.01 & 0.000 & 0.030 & 0.31 & 0.002 & 0.040 & 0.39 & 0.003 \\
\hline $\begin{array}{l}\text { NEVER MARRIED } \\
\text { Employment Status }\end{array}$ & $0.123 * * *$ & 3.24 & 0.010 & $0.121^{* * *}$ & 3.24 & 0.011 & $0.135^{* * *}$ & 3.58 & 0.012 & $0.128 * * *$ & 3.29 & 0.011 \\
\hline PART TIME EMPLOYEE & $0.141^{* * *}$ & 3.09 & 0.012 & $0.159 * * *$ & 3.54 & 0.015 & $0.158 * * *$ & 3.45 & 0.015 & $0.151 * * *$ & 3.22 & 0.013 \\
\hline SELFEMPLOYED & 0.085 & 1.63 & 0.007 & $0.087^{*}$ & 1.67 & 0.008 & 0.086 & 1.63 & 0.008 & $0.096^{*}$ & 1.81 & 0.008 \\
\hline UNEMPLOYED & $-0.099 * *$ & -1.97 & -0.007 & $-0.091 * *$ & -1.82 & -0.007 & -0.076 & -1.51 & -0.006 & -0.068 & -1.32 & -0.005 \\
\hline
\end{tabular}




\begin{tabular}{|c|c|c|c|c|c|c|c|c|c|c|c|c|}
\hline AT HOME & $-0.114^{* *}$ & -2.19 & -0.008 & $-0.105^{* *}$ & -2.06 & -0.008 & $-0.087^{*}$ & -1.69 & -0.007 & $-0.094^{*}$ & -1.76 & -0.007 \\
\hline STUDENT & -0.041 & -0.66 & -0.003 & -0.007 & -0.12 & -0.001 & -0.037 & -0.60 & -0.003 & -0.061 & -0.96 & -0.005 \\
\hline RETIRED & $-0.252 * * *$ & -3.96 & -0.016 & $-0.227 * * *$ & -3.61 & -0.016 & $-0.206^{* * *}$ & -3.30 & -0.014 & $-0.219 * * *$ & -3.37 & -0.014 \\
\hline OTHER & 0.138 & 1.48 & 0.012 & $0.170 *$ & 1.85 & 0.016 & $0.166^{*}$ & 1.80 & 0.016 & 0.151 & 1.59 & 0.013 \\
\hline Region & & & & & & & & & & & & \\
\hline WESTERN EUROPE & $0.595 * * *$ & 20.91 & 0.047 & $0.554 * * *$ & 19.90 & 0.046 & 0.454 & 16.38 & 0.037 & $0.522 * * *$ & 17.99 & 0.040 \\
\hline Pseudo R2 & 0.101 & & & 0.086 & & & 0.093 & & & 0.114 & & \\
\hline Number of observations & 36086 & & & 36052 & & & 36237 & & & 34428 & & \\
\hline Prob > chi2 & 0.000 & & & 0.000 & & & 0.000 & & & 0.000 & & \\
\hline
\end{tabular}

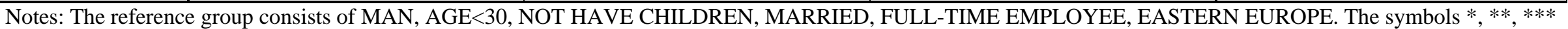
represent statistical significance at the $10 \%, 5 \%$ and $1 \%$ levels, respectively. Robust standard errors. 
Table 2: Determinants of Unpaid Work in Environmental Organizations

\begin{tabular}{|c|c|c|c|c|c|c|c|c|c|c|c|c|}
\hline & \multicolumn{12}{|c|}{ WEIGHTED PROBIT } \\
\hline & \multicolumn{3}{|c|}{ (5) } & \multicolumn{3}{|c|}{ (6) } & \multicolumn{3}{|c|}{ (7) } & \multicolumn{3}{|c|}{ (8) } \\
\hline & Coeff. & z-Stat. & Marg. & Coeff. & z-Stat. & Marg. & Coeff. & z-Stat. & Marg. & Coeff. & z-Stat. & Marg. \\
\hline $\begin{array}{l}\text { Environmental } \\
\text { Motivation }(\boldsymbol{m}) \\
\text { WILLINGNESS TO } \\
\text { GIVE INCOME } \\
\text { WILLINGNESS TO } \\
\text { INCREASE TAXES } \\
\text { CONTRIBUTE AT NO } \\
\text { COSTS } \\
\text { Gender }\end{array}$ & $0.233^{* * *}$ & 10.45 & 0.009 & $0.162 * * *$ & 7.89 & 0.007 & $-0.091 * * *$ & -4.83 & -0.004 & $\begin{array}{l}0.204^{* * *} \\
0.045^{*} \\
-0.028\end{array}$ & $\begin{array}{l}7.47 \\
1.83 \\
-1.39\end{array}$ & $\begin{array}{r}0.008 \\
0.002 \\
-0.001\end{array}$ \\
\hline $\begin{array}{l}\text { FEMALE } \\
\text { Age }\end{array}$ & $-0.100 * * *$ & -2.79 & -0.004 & $-0.085^{* *}$ & -2.40 & -0.004 & $-0.092 * *$ & -2.61 & -0.004 & $-0.094 * *$ & -2.55 & -0.004 \\
\hline AGE 30-39 & 0.017 & 0.30 & 0.001 & 0.018 & 0.31 & 0.001 & 0.029 & 0.52 & 0.001 & 0.019 & 0.33 & 0.001 \\
\hline AGE 40-49 & 0.094 & 1.58 & 0.004 & 0.077 & 1.32 & 0.003 & 0.090 & 1.54 & 0.004 & 0.081 & 1.34 & 0.003 \\
\hline AGE 50-59 & $0.126^{*}$ & 1.96 & 0.005 & $0.127 * *$ & 2.02 & 0.006 & $0.141 * *$ & 2.22 & 0.006 & $0.116^{*}$ & 1.77 & 0.005 \\
\hline AGE 60-69 & 0.123 & 1.51 & 0.005 & 0.096 & 1.18 & 0.004 & 0.116 & 1.42 & 0.005 & 0.110 & 1.30 & 0.005 \\
\hline $\begin{array}{l}\text { AGE } 70+ \\
\text { Parental Effect }\end{array}$ & 0.101 & 0.92 & 0.004 & 0.055 & 0.50 & 0.002 & 0.035 & 0.31 & 0.001 & 0.049 & 0.42 & 0.002 \\
\hline $\begin{array}{l}\text { CHILD } \\
\text { Formal and Informal } \\
\text { Educ. }\end{array}$ & -0.106 & -1.22 & -0.004 & -0.115 & -1.35 & -0.004 & -0.101 & -1.19 & -0.004 & -0.082 & -0.94 & -0.003 \\
\hline EDUCATION & $0.019 * * *$ & 7.13 & 0.001 & $0.020 * * *$ & 7.40 & 0.001 & $0.021^{* * *}$ & 7.90 & 0.001 & $0.019 * * *$ & 6.71 & 0.001 \\
\hline $\begin{array}{l}\text { POLITICAL } \\
\text { DISCUSSION } \\
\text { Marital Status }\end{array}$ & $0.110^{* * *}$ & 3.98 & 0.004 & $0.119 * * *$ & 4.37 & 0.005 & $0.115^{* * *}$ & 4.28 & 0.005 & $0.099 * * *$ & 3.53 & 0.004 \\
\hline WIDOWED & -0.023 & -0.28 & -0.001 & -0.062 & -0.74 & -0.002 & -0.060 & -0.72 & -0.002 & -0.049 & -0.56 & -0.002 \\
\hline DIVORCED & -0.100 & -1.50 & -0.004 & -0.091 & -1.40 & -0.003 & -0.102 & -1.56 & -0.004 & -0.103 & -1.53 & -0.004 \\
\hline SEPARATED & 0.160 & 1.22 & 0.007 & 0.148 & 1.15 & 0.007 & 0.161 & 1.25 & 0.008 & 0.181 & 1.36 & 0.009 \\
\hline NEVER MARRIED & $0.139 * * *$ & 2.92 & 0.006 & $0.138 * * *$ & 2.95 & 0.006 & $0.144^{* * *}$ & 3.07 & 0.007 & $0.144^{* * *}$ & 2.96 & 0.006 \\
\hline
\end{tabular}




\begin{tabular}{|c|c|c|c|c|c|c|c|c|c|c|c|c|}
\hline \multicolumn{13}{|l|}{ Employment Status } \\
\hline $\begin{array}{l}\text { PART TIME } \\
\text { EMPLOYEE }\end{array}$ & 0.064 & 0.99 & 0.003 & 0.071 & 1.13 & 0.003 & 0.080 & 1.28 & 0.004 & 0.065 & 0.99 & 0.003 \\
\hline SELFEMPLOYED & -0.036 & -0.50 & -0.001 & -0.028 & -0.39 & -0.001 & -0.041 & -0.57 & -0.002 & -0.034 & -0.46 & -0.001 \\
\hline UNEMPLOYED & -0.114 & -1.60 & -0.004 & -0.095 & -1.35 & -0.004 & -0.103 & -1.46 & -0.004 & -0.096 & -1.31 & -0.004 \\
\hline AT HOME & $-0.163 * *$ & -2.13 & -0.006 & $-0.137 *$ & -1.85 & -0.005 & $-0.140 *$ & -1.88 & -0.005 & $-0.161^{* *}$ & -2.07 & -0.005 \\
\hline STUDENT & 0.073 & 1.02 & 0.003 & $0.119 *$ & 1.69 & 0.005 & 0.100 & 1.43 & 0.005 & 0.068 & 0.94 & 0.003 \\
\hline RETIRED & $-0.310 * * *$ & -3.79 & -0.009 & $-0.310 * * *$ & -3.82 & -0.010 & $-0.317 * * *$ & -3.90 & -0.010 & $-0.299 * * *$ & -3.59 & -0.009 \\
\hline OTHER & 0.139 & 1.14 & 0.006 & 0.146 & 1.21 & 0.007 & 0.140 & 1.16 & 0.007 & 0.157 & 1.27 & 0.007 \\
\hline Region & & & & & & & & & & & & \\
\hline WESTERN EUROPE & $0.092^{* * *}$ & 2.69 & 0.004 & $0.069 * *$ & 2.04 & 0.003 & 0.024 & 0.69 & 0.001 & $0.069 *$ & 1.93 & 0.003 \\
\hline Pseudo R2 & 0.053 & & & 0.043 & & & 0.037 & & & 0.055 & & \\
\hline Number of observations & 36086 & & & 36052 & & & 36237 & & & 34428 & & \\
\hline Prob > chi2 & 0.000 & & & 0.000 & & & 0.000 & & & 0.000 & & \\
\hline
\end{tabular}

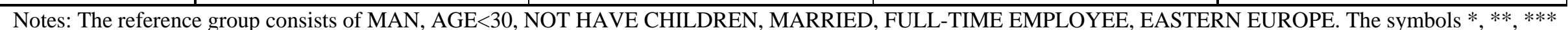

represent statistical significance at the $10 \%, 5 \%$ and $1 \%$ levels, respectively. Robust standard errors. 
Table 3: Income and Membership in Environmental Organizations

\begin{tabular}{|c|c|c|c|c|c|c|c|c|c|c|c|c|}
\hline & \multicolumn{12}{|c|}{ WEIGHTED PROBIT } \\
\hline & \multicolumn{3}{|l|}{ (9) } & \multicolumn{3}{|l|}{ (10) } & \multicolumn{3}{|l|}{ (11) } & \multicolumn{3}{|l|}{ (12) } \\
\hline & Coeff. & z-Stat. & Marg. & Coeff. & z-Stat. & Marg. & Coeff. & z-Stat. & Marg. & Coeff. & z-Stat. & Marg. \\
\hline 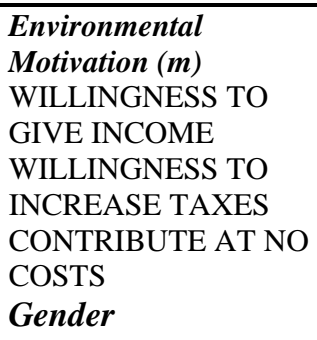 & $0.295 * * *$ & 12.87 & 0.023 & $0.196 * * *$ & 9.44 & 0.016 & $-0.205^{* * *}$ & -10.37 & -0.017 & $\begin{array}{l}0.264^{* * *} \\
0.008 \\
-0.141^{* * *}\end{array}$ & $\begin{array}{l}9.15 \\
0.31 \\
-6.77\end{array}$ & $\begin{array}{l}0.020 \\
0.001 \\
-0.011\end{array}$ \\
\hline $\begin{array}{l}\text { FEMALE } \\
\text { Age }\end{array}$ & $0.083^{* *}$ & 2.02 & 0.006 & $0.090 * *$ & 2.22 & 0.007 & $0.084 * *$ & 2.07 & 0.007 & $0.085^{* *}$ & 2.03 & 0.007 \\
\hline AGE 30-39 & -0.058 & -0.88 & -0.004 & -0.055 & -0.85 & -0.004 & -0.043 & -0.66 & -0.003 & -0.059 & -0.88 & -0.004 \\
\hline AGE 40-49 & 0.011 & 0.16 & 0.001 & -0.014 & -0.20 & -0.001 & 0.002 & 0.03 & 0.000 & 0.013 & 0.19 & 0.001 \\
\hline AGE 50-59 & $0.141^{*}$ & 1.93 & 0.012 & $0.120 *$ & 1.65 & 0.011 & $0.154^{* *}$ & 2.09 & 0.014 & $0.148 *$ & 1.95 & 0.012 \\
\hline $\begin{array}{l}\text { AGE } 70+ \\
\text { Parental Effect }\end{array}$ & -0.051 & -0.45 & -0.004 & -0.102 & -0.89 & -0.008 & -0.108 & -0.93 & -0.008 & -0.099 & -0.82 & -0.007 \\
\hline $\begin{array}{l}\text { CHILD } \\
\text { Formal and Informal } \\
\text { Educ. }\end{array}$ & -0.044 & -0.54 & -0.003 & -0.044 & -0.54 & -0.004 & -0.039 & -0.47 & -0.003 & -0.030 & -0.35 & -0.002 \\
\hline EDUCATION & $0.026 * * *$ & 7.54 & 0.002 & $0.026 * * *$ & 7.78 & 0.002 & $0.027 * * *$ & 7.95 & 0.002 & $0.024 * * *$ & 6.79 & 0.002 \\
\hline $\begin{array}{l}\text { POLITICAL } \\
\text { DISCUSSION } \\
\text { Economic Situation }\end{array}$ & $0.147 * * *$ & 4.99 & 0.012 & $0.155^{* * *}$ & 5.29 & 0.013 & $0.138 * * *$ & 4.70 & 0.011 & $0.123^{* * *}$ & 4.06 & 0.009 \\
\hline UPPER CLASS & $0.142 * * *$ & 2.65 & 0.012 & $0.163^{* * *}$ & 3.06 & 0.015 & $0.156 * * *$ & 2.89 & 0.014 & $0.125^{* *}$ & 2.26 & 0.010 \\
\hline $\begin{array}{l}\text { MIDDLE CLASS } \\
\text { Marital Status }\end{array}$ & $0.087 * *$ & 2.04 & 0.007 & $0.092 * *$ & 2.19 & 0.008 & $0.083 *$ & 1.95 & 0.007 & $0.079 *$ & 1.79 & 0.006 \\
\hline WIDOWED & -0.067 & -0.75 & -0.005 & -0.122 & -1.35 & -0.009 & -0.095 & -1.06 & -0.007 & -0.104 & -1.09 & -0.007 \\
\hline DIVORCED & -0.079 & -1.06 & -0.006 & -0.094 & -1.27 & -0.007 & -0.108 & -1.43 & -0.008 & -0.088 & -1.14 & -0.006 \\
\hline
\end{tabular}




\begin{tabular}{|c|c|c|c|c|c|c|c|c|c|c|c|c|}
\hline SEPARATED & 0.015 & 0.10 & 0.001 & 0.016 & 0.11 & 0.001 & 0.050 & 0.36 & 0.004 & 0.048 & 0.33 & 0.004 \\
\hline NEVER MARRIED & 0.001 & 0.01 & 0.000 & 0.002 & 0.04 & 0.000 & 0.017 & 0.29 & 0.001 & 0.013 & 0.23 & 0.001 \\
\hline \multicolumn{13}{|l|}{ Employment Status } \\
\hline PART TIME & 0.088 & 1.21 & 0.007 & 0.108 & 1.53 & 0.010 & 0.093 & 1.29 & 0.008 & 0.091 & 1.22 & 0.007 \\
\hline \multicolumn{13}{|l|}{ EMPLOYEE } \\
\hline SELFEMPLOYED & 0.059 & 0.75 & 0.005 & 0.055 & 0.72 & 0.005 & 0.063 & 0.81 & 0.005 & 0.074 & 0.95 & 0.006 \\
\hline UNEMPLOYED & -0.029 & -0.42 & -0.002 & -0.027 & -0.38 & -0.002 & -0.017 & -0.24 & -0.001 & -0.013 & -0.18 & -0.001 \\
\hline AT HOME & $-0.176^{* *}$ & -2.40 & -0.012 & $-0.158 * *$ & -2.20 & -0.012 & $-0.146 * *$ & -2.01 & -0.011 & $-0.172 * *$ & -2.27 & -0.012 \\
\hline RETIRED & -0.041 & -0.50 & -0.003 & -0.028 & -0.34 & -0.002 & -0.022 & -0.27 & -0.002 & -0.036 & -0.43 & -0.003 \\
\hline OTHER & 0.092 & 0.64 & 0.008 & 0.093 & 0.65 & 0.008 & 0.101 & 0.71 & 0.009 & 0.116 & 0.79 & 0.010 \\
\hline \multicolumn{13}{|l|}{ Region } \\
\hline WESTERN EUROPE & $0.355^{* * *}$ & 8.06 & 0.026 & $0.301 * * *$ & 7.02 & 0.023 & $0.254^{* * *}$ & 5.93 & 0.019 & $0.334 * * *$ & 7.39 & 0.023 \\
\hline Pseudo R2 & 0.070 & & & 0.066 & & & 0.070 & & & 0.094 & & \\
\hline $\begin{array}{l}\text { Number of } \\
\text { observations }\end{array}$ & 18862 & & & 18887 & & & 18877 & & & 18155 & & \\
\hline
\end{tabular}

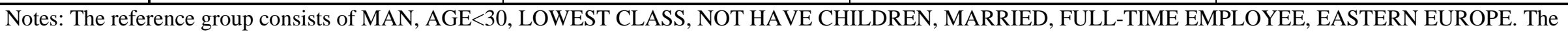
symbols *, **, *** represent statistical significance at the $10 \%, 5 \%$ and $1 \%$ levels, respectively. Robust standard errors. 
Table 4: Income and Unpaid Work in Environmental Organizations

\begin{tabular}{|c|c|c|c|c|c|c|c|c|c|c|c|c|}
\hline & \multicolumn{12}{|c|}{ WEIGHTED PROBIT } \\
\hline & \multicolumn{3}{|c|}{ (13) } & \multicolumn{3}{|l|}{ (14) } & \multicolumn{3}{|l|}{ (15) } & \multicolumn{3}{|l|}{ (16) } \\
\hline & Coeff. & z-Stat. & Marg. & Coeff. & z-Stat. & Marg. & Coeff. & z-Stat. & Marg. & Coeff. & z-Stat. & Marg. \\
\hline $\begin{array}{l}\text { Environmental } \\
\text { Motivation (m) } \\
\text { WILLINGNESS TO } \\
\text { GIVE INCOME } \\
\text { WILLINGNESS TO } \\
\text { INCREASE TAXES } \\
\text { CONTRIBUTE AT NO } \\
\text { COSTS } \\
\text { Gender }\end{array}$ & $0.231 * * *$ & 8.06 & 0.010 & $0.153 * * *$ & 5.77 & 0.007 & $-0.138 * * *$ & -5.44 & -0.006 & $\begin{array}{l}0.212^{* * *} \\
0.008 \\
-0.084^{* * *}\end{array}$ & $\begin{array}{l}5.98 \\
0.26 \\
-3.18\end{array}$ & $\begin{array}{c}0.009 \\
0.0003 \\
-0.003\end{array}$ \\
\hline $\begin{array}{l}\text { FEMALE } \\
\text { Age }\end{array}$ & $-0.158 * * *$ & -3.04 & -0.007 & $-0.144 * * *$ & -2.80 & -0.006 & $-0.145^{* * *}$ & -2.80 & -0.006 & $-0.155^{* * *}$ & -2.90 & -0.006 \\
\hline AGE 30-39 & 0.011 & 0.14 & 0.000 & 0.009 & 0.11 & 0.000 & 0.027 & 0.34 & 0.001 & 0.015 & 0.18 & 0.001 \\
\hline AGE 40-49 & 0.006 & 0.06 & 0.000 & -0.007 & -0.08 & 0.000 & 0.005 & 0.06 & 0.000 & 0.001 & 0.01 & 0.000 \\
\hline AGE 50-59 & 0.099 & 1.09 & 0.004 & 0.088 & 0.99 & 0.004 & 0.111 & 1.23 & 0.005 & 0.089 & 0.95 & 0.004 \\
\hline AGE 60-69 & 0.040 & 0.36 & 0.002 & 0.016 & 0.15 & 0.001 & 0.038 & 0.34 & 0.002 & 0.030 & 0.26 & 0.001 \\
\hline $\begin{array}{l}\text { AGE } 70+ \\
\text { Parental Effect }\end{array}$ & 0.052 & 0.35 & 0.002 & 0.012 & 0.08 & 0.001 & -0.030 & -0.19 & -0.001 & -0.013 & -0.08 & -0.001 \\
\hline $\begin{array}{l}\text { CHILD } \\
\text { Formal and Informal } \\
\text { Educ. }\end{array}$ & -0.042 & -0.35 & -0.002 & -0.039 & -0.33 & -0.002 & -0.016 & -0.14 & -0.001 & -0.005 & -0.04 & 0.000 \\
\hline EDUCATION & $0.022 * * *$ & 5.43 & 0.001 & $0.023^{* * *}$ & 5.62 & 0.001 & $0.023 * * *$ & 5.68 & 0.001 & $0.021^{* * *}$ & 4.85 & 0.001 \\
\hline $\begin{array}{l}\text { POLITICAL } \\
\text { DISCUSSION } \\
\text { Economic Situation }\end{array}$ & $0.064 *$ & 1.68 & 0.003 & $0.066^{*}$ & 1.78 & 0.003 & 0.055 & 1.48 & 0.002 & 0.039 & 1.01 & 0.002 \\
\hline UPPER CLASS & $0.237 * * *$ & 3.58 & 0.012 & $0.254 * * *$ & 3.91 & 0.014 & $0.255^{* * *}$ & 3.83 & 0.013 & $0.241^{* * *}$ & 3.54 & 0.012 \\
\hline $\begin{array}{l}\text { MIDDLE CLASS } \\
\text { Marital Status }\end{array}$ & $0.153^{* * *}$ & 2.79 & 0.007 & $0.156^{* * *}$ & 2.88 & 0.007 & $0.161^{* * *}$ & 2.93 & 0.007 & $0.166^{* * *}$ & 2.95 & 0.007 \\
\hline WIDOWED & 0.029 & 0.25 & 0.001 & -0.006 & -0.05 & 0.000 & 0.011 & 0.09 & 0.000 & -0.007 & -0.06 & 0.000 \\
\hline DIVORCED & -0.077 & -0.85 & -0.003 & -0.085 & -0.94 & -0.003 & -0.106 & -1.16 & -0.004 & -0.095 & -1.03 & -0.004 \\
\hline
\end{tabular}




\begin{tabular}{|c|c|c|c|c|c|c|c|c|c|c|c|c|}
\hline SEPARATED & 0.082 & 0.45 & 0.004 & 0.075 & 0.42 & 0.004 & 0.102 & 0.56 & 0.005 & 0.104 & 0.55 & 0.005 \\
\hline NEVER MARRIED & 0.052 & 0.76 & 0.002 & 0.056 & 0.83 & 0.003 & 0.071 & 1.02 & 0.003 & 0.069 & 0.99 & 0.003 \\
\hline \multicolumn{13}{|l|}{ Employment Status } \\
\hline PART TIME & 0.038 & 0.40 & 0.002 & 0.062 & 0.69 & 0.003 & 0.055 & 0.59 & 0.002 & 0.048 & 0.50 & 0.002 \\
\hline \multicolumn{13}{|l|}{ EMPLOYEE } \\
\hline SELFEMPLOYED & -0.015 & -0.16 & -0.001 & -0.010 & -0.11 & 0.000 & -0.024 & -0.25 & -0.001 & -0.018 & -0.19 & -0.001 \\
\hline UNEMPLOYED & -0.071 & -0.77 & -0.003 & -0.063 & -0.69 & -0.003 & -0.054 & -0.58 & -0.002 & -0.058 & -0.61 & -0.002 \\
\hline AT HOME & -0.160 & -1.62 & -0.006 & -0.141 & -1.48 & -0.006 & -0.144 & -1.49 & -0.006 & -0.158 & -1.57 & -0.006 \\
\hline STUDENT & 0.002 & 0.02 & 0.000 & 0.024 & 0.23 & 0.001 & 0.007 & 0.07 & 0.000 & 0.000 & 0.00 & 0.000 \\
\hline RETIRED & $-0.209 *$ & -1.90 & -0.007 & $-0.203^{*}$ & -1.87 & -0.007 & $-0.204 *$ & -1.86 & -0.007 & $-0.199 *$ & -1.76 & -0.007 \\
\hline OTHER & 0.224 & 1.42 & 0.012 & 0.222 & 1.42 & 0.012 & 0.229 & 1.46 & 0.012 & 0.252 & 1.56 & 0.013 \\
\hline \multicolumn{13}{|l|}{ Region } \\
\hline WESTERN EUROPE & $0.119 * *$ & 2.32 & 0.005 & $0.087 *$ & 1.71 & 0.004 & 0.057 & 1.12 & 0.002 & $0.110 * *$ & 2.07 & 0.004 \\
\hline Pseudo R2 & 0.063 & & & 0.053 & & & 0.053 & & & 0.070 & & \\
\hline Number of observations & 18862 & & & 18887 & & & 18877 & & & 18155 & & \\
\hline Prob > chi2 & 0.000 & & & 0.000 & & & 0.000 & & & 0.000 & & \\
\hline
\end{tabular}

symbols $*, * *, * * *$ represent statistical significance at the $10 \%, 5 \%$ and $1 \%$ levels, respectively. Robust standard errors. 
Table 5: 2SLS Focusing on Environmental Membership

\begin{tabular}{|c|c|c|c|c|c|c|c|c|c|c|c|c|}
\hline \multirow[t]{2}{*}{ WEIGHTED 2SLS } & \multirow{2}{*}{$\begin{array}{l}\text { 2SLS } \\
\text { Coeff. }\end{array}$} & \multirow{2}{*}{$\begin{array}{l}(17) \\
\text { t-Stat. }\end{array}$} & \multicolumn{2}{|c|}{$\begin{array}{l}\text { FIRST } \\
\text { STAGE } \\
\text { REGRESSION } \\
\end{array}$} & \multirow{2}{*}{$\begin{array}{l}\text { 2SLS } \\
\text { Coeff. }\end{array}$} & \multirow{2}{*}{$\begin{array}{l}\text { (18) } \\
\text { t-Stat. }\end{array}$} & \multicolumn{2}{|c|}{$\begin{array}{l}\text { FIRST } \\
\text { STAGE } \\
\text { REGRESSION }\end{array}$} & 2SLS & (19) & \multicolumn{2}{|c|}{$\begin{array}{l}\text { FIRST } \\
\text { STAGE } \\
\text { REGRESSION } \\
\end{array}$} \\
\hline & & & Coeff. & t-Stat. & & & Coeff. & t-Stat. & Coeff. & t-Stat. & t-Stat. & Coeff. \\
\hline $\begin{array}{l}\text { FEMALE } \\
\text { Age }\end{array}$ & $-0.019 * *$ & -2.09 & $0.075^{* * *}$ & 6.20 & -0.005 & -1.07 & $0.059 * * *$ & 4.92 & 0.001 & 0.16 & $-0.025^{* *}$ & -2.07 \\
\hline AGE 30-39 & $0.014^{*}$ & 1.78 & -0.028 & -1.51 & 0.010 & 1.53 & -0.023 & -1.23 & $0.016^{* *}$ & 2.28 & $0.043 * *$ & 2.17 \\
\hline AGE 40-49 & $0.032 * * *$ & 3.28 & $-0.060 * * *$ & -2.98 & $0.013 * *$ & 1.97 & -0.011 & -0.55 & $0.017 * *$ & 2.33 & 0.019 & 0.89 \\
\hline AGE 50-59 & $0.048 * * *$ & 4.48 & $-0.065 * * *$ & -2.95 & $0.031^{* * *}$ & 4.20 & -0.029 & -1.34 & $0.041^{* * *}$ & 4.89 & $0.055^{* *}$ & 2.42 \\
\hline $\begin{array}{l}\text { AGE } 70+ \\
\text { Parental Effect }\end{array}$ & $0.073 * * *$ & 3.86 & $-0.148 * * *$ & -4.51 & $0.034^{* * *}$ & 3.12 & $-0.059 *$ & -1.83 & $0.049 * * *$ & 3.85 & $0.109 * * *$ & 3.34 \\
\hline $\begin{array}{l}\text { CHILD } \\
\text { Formal and Informal } \\
\text { Educ. }\end{array}$ & -0.008 & -0.89 & -0.002 & -0.11 & $-0.014^{*}$ & -1.92 & 0.018 & 0.86 & $-0.023 * * *$ & -2.90 & $-0.050 * *$ & -2.34 \\
\hline EDUCATION & -0.002 & -1.40 & $0.017 * * *$ & 15.84 & 0.000 & -0.39 & $0.017 * * *$ & 15.26 & -0.001 & -0.99 & $-0.018 * * *$ & -15.62 \\
\hline $\begin{array}{l}\text { POLITICAL } \\
\text { DISCUSSION } \\
\text { Marital Status }\end{array}$ & $-0.033 * *$ & -2.27 & $0.143^{* * *}$ & 15.91 & $-0.013^{*}$ & -1.76 & $0.131^{* * *}$ & 14.66 & $-0.022 * *$ & -2.24 & $-0.148 * * *$ & -16.42 \\
\hline WIDOWED & $0.024^{*}$ & 1.77 & $-0.093 * * *$ & -3.92 & 0.004 & 0.47 & $-0.065 * * *$ & -2.79 & 0.001 & 0.17 & $0.043^{*}$ & 1.89 \\
\hline DIVORCED & $0.024 * *$ & 2.03 & $-0.079 * * *$ & -3.50 & 0.013 & 1.61 & $-0.073 * * *$ & -3.27 & 0.013 & 1.49 & $0.064 * * *$ & 2.92 \\
\hline SEPARATED & -0.004 & -0.19 & 0.020 & 0.48 & 0.007 & 0.45 & -0.014 & -0.32 & 0.022 & 1.33 & 0.069 & 1.62 \\
\hline NEVER MARRIED & $0.025 * * *$ & 3.25 & $-0.029 *$ & -1.65 & $0.022 * * *$ & 3.61 & $-0.032 *$ & -1.89 & $0.021 * * *$ & 3.27 & 0.021 & 1.16 \\
\hline
\end{tabular}




\begin{tabular}{|c|c|c|c|c|c|c|c|c|c|c|c|c|}
\hline \multicolumn{13}{|l|}{ Employment Status } \\
\hline $\begin{array}{l}\text { PART TIME } \\
\text { EMPLOYEE }\end{array}$ & 0.009 & 0.89 & 0.030 & 1.34 & $0.016^{*}$ & 1.96 & 0.019 & 0.87 & 0.014 & 1.62 & -0.024 & -1.03 \\
\hline SELFEMPLOYED & -0.013 & -1.13 & $0.071^{* * *}$ & 3.10 & 0.001 & 0.09 & $0.045^{*}$ & 1.93 & -0.006 & -0.59 & $-0.062 * *$ & -2.52 \\
\hline AT HOME & -0.009 & -1.00 & -0.001 & -0.04 & -0.001 & -0.20 & $-0.038 *$ & -1.75 & $0.016 *$ & 1.69 & $0.096 * * *$ & 4.32 \\
\hline STUDENT & $-0.040 * * *$ & -2.85 & $0.082 * * *$ & 2.97 & -0.015 & -1.55 & 0.032 & 1.15 & $-0.034 * * *$ & -2.92 & $-0.092 * * *$ & -3.16 \\
\hline RETIRED & 0.021 & 1.48 & $-0.114 * * *$ & -4.86 & 0.005 & 0.66 & $-0.105^{* * *}$ & -4.71 & $0.025 * *$ & 2.05 & $0.163^{* * *}$ & 7.54 \\
\hline \multicolumn{13}{|l|}{ Region } \\
\hline WESTERN EUROPE & $0.111^{* * *}$ & 6.25 & $-0.177 * * *$ & -15.69 & $0.073 * * *$ & 11.40 & $-0.106 * * *$ & -9.42 & -0.024 & -1.37 & $-0.271 * * *$ & -23.66 \\
\hline \multicolumn{13}{|l|}{ Instrument: } \\
\hline PERCEIVED & & & $-0.009 * * *$ & -4.06 & & & $-0.014 * * *$ & -6.20 & & & $0.012 * * *$ & 5.30 \\
\hline LEVEL OF & & & & & & & & & & & & \\
\hline DISHONESTY & & & & & & & & & & & & \\
\hline $\begin{array}{l}\text { Test of excluded } \\
\text { instruments }\end{array}$ & & & $16.45^{* * *}$ & & & & 38.50 & & & & $28.10^{* * *}$ & \\
\hline $\begin{array}{l}\text { Anderson canon. cor. } \\
\text { LR statistic }\end{array}$ & $21.552 * * *$ & & & & $47.697 * * *$ & & & & $32.857 * * *$ & & & \\
\hline Anderson-Rubin test & $43.86 * * *$ & & & & $41.73 * * *$ & & & & $40.040 * * *$ & & & \\
\hline
\end{tabular}

Notes: The reference group consists of MAN, AGE<30, NOT HAVE CHILDREN, MARRIED, FULL-TIME EMPLOYEE, EASTERN EUROPE. The symbols *, **, *** represent statistical significance at the $10 \%, 5 \%$ and $1 \%$ levels, respectively. Robust standard errors. 
Table 6: The Impact of Environmental Motivation on Membership Participation in Single Countries

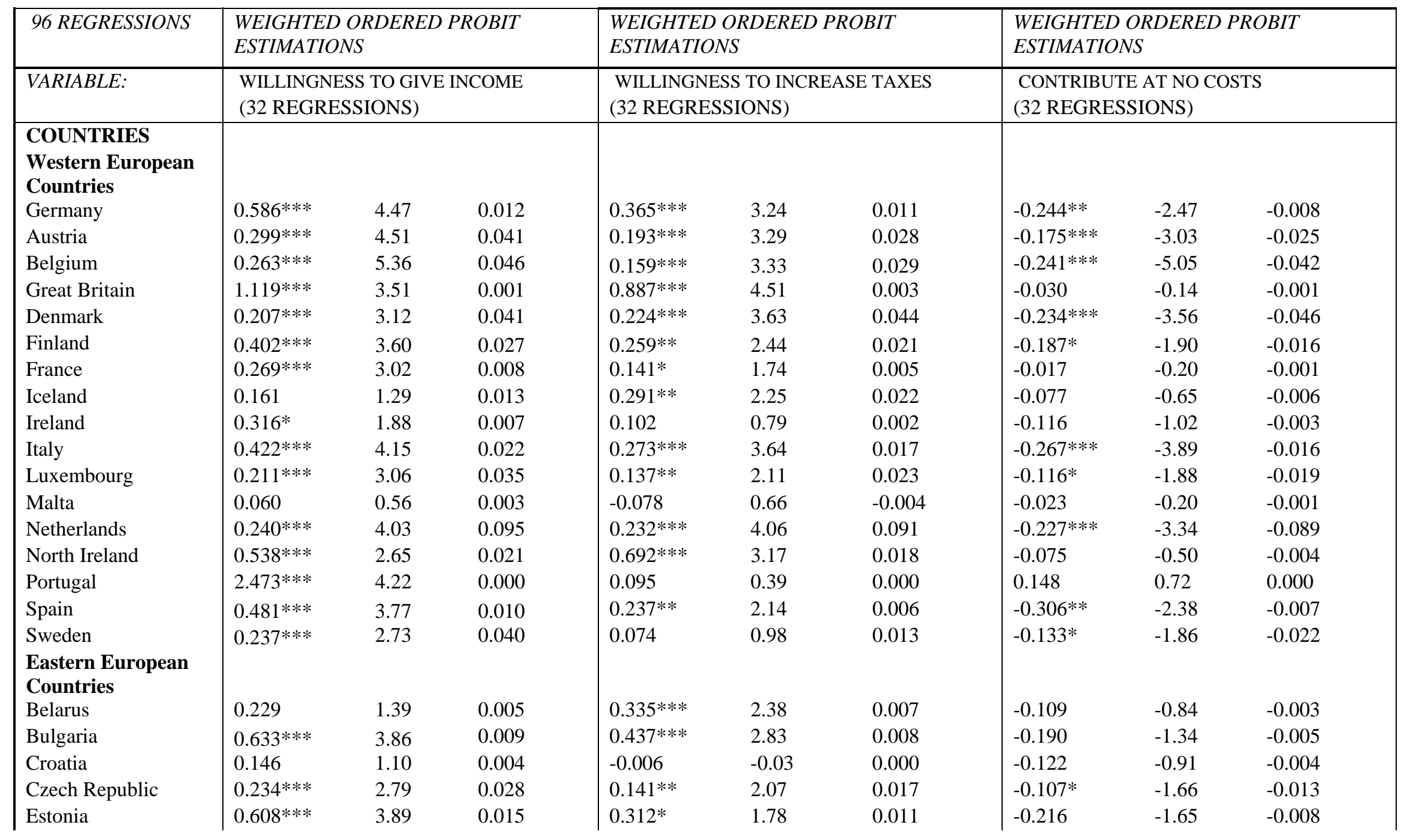




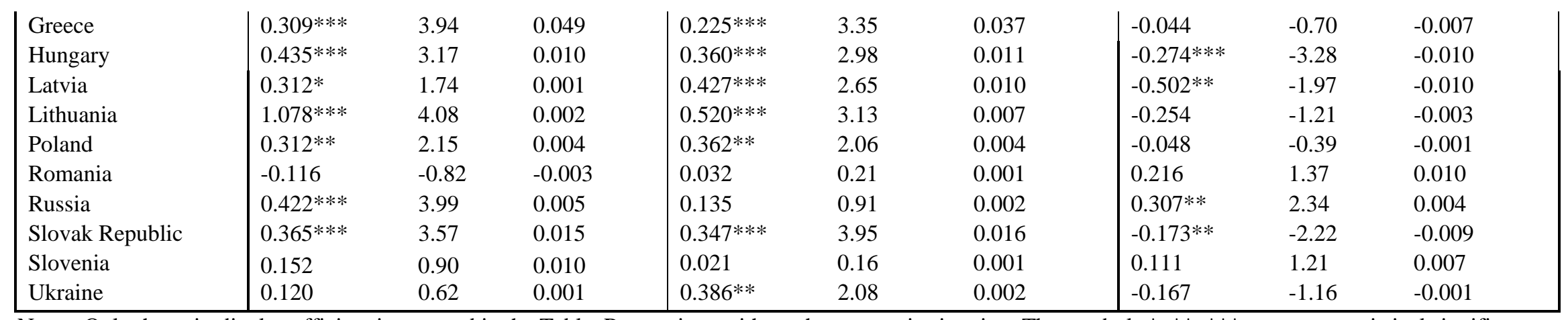

Notes: Only the attitudinal coefficient is reported in the Table. Regressions without the economic situation. The symbols *, **, *** represent statistical significance at the $10 \%, 5 \%$ and $1 \%$ levels, respectively. Robust standard errors. 
Table 7: The Impact of Environmental Motivation on Unpaid Work in Single Countries

\begin{tabular}{|c|c|c|c|c|c|c|c|c|c|}
\hline 96 REGRESSIONS & \multicolumn{3}{|c|}{$\begin{array}{l}\text { WEIGHTED ORDERED PROBIT } \\
\text { ESTIMATIONS }\end{array}$} & \multicolumn{3}{|c|}{$\begin{array}{l}\text { WEIGHTED ORDERED PROBIT } \\
\text { ESTIMATIONS }\end{array}$} & \multicolumn{3}{|c|}{$\begin{array}{l}\text { WEIGHTED ORDERED PROBIT } \\
\text { ESTIMATIONS }\end{array}$} \\
\hline VARIABLE: & \multicolumn{3}{|c|}{$\begin{array}{l}\text { WILLINGNESS TO GIVE INCOME } \\
\text { (32 REGRESSIONS) }\end{array}$} & \multicolumn{3}{|c|}{$\begin{array}{l}\text { WILLINGNESS TO INCREASE TAXES } \\
\text { (32 REGRESSIONS) }\end{array}$} & \multicolumn{3}{|c|}{$\begin{array}{l}\text { CONTRIBUTE AT NO COSTS } \\
\text { (32 REGRESSIONS) }\end{array}$} \\
\hline \multirow{2}{*}{\multicolumn{10}{|c|}{$\begin{array}{l}\text { COUNTRIES } \\
\text { Western European } \\
\text { Countries }\end{array}$}} \\
\hline & & & & & & & & & \\
\hline Germany & $0.650 * * *$ & 3.40 & 0.004 & $0.607 * * *$ & 4.14 & 0.005 & $-0.330 * *$ & -2.13 & -0.005 \\
\hline Austria & $0.164^{*}$ & 1.71 & 0.007 & 0.044 & 0.52 & 0.002 & -0.117 & -1.56 & -0.006 \\
\hline Belgium & $0.107^{*}$ & 1.68 & 0.006 & 0.073 & 1.13 & 0.004 & 0.006 & 0.08 & 0.000 \\
\hline Great Britain & $0.229 * *$ & 2.11 & 0.024 & 0.110 & 1.04 & 0.012 & $-0.171^{*}$ & -1.68 & -0.017 \\
\hline Denmark & 0.193 & 1.61 & 0.007 & 0.058 & 0.60 & 0.002 & -0.181 & -1.52 & -0.007 \\
\hline Finland & 0.198 & 1.07 & 0.007 & 0.254 & 1.40 & 0.007 & -0.156 & -1.27 & -0.005 \\
\hline France & $0.226 * *$ & 2.03 & 0.003 & 0.150 & 1.30 & 0.002 & -0.085 & -0.79 & -0.001 \\
\hline Iceland & 0.339 & 1.35 & 0.009 & 0.328 & 1.56 & 0.009 & 0.019 & 0.12 & 0.001 \\
\hline Ireland & -0.132 & -0.65 & 0.000 & -0.038 & -0.21 & 0.000 & 0.154 & 0.77 & 0.000 \\
\hline Italy & $0.410 * * *$ & 3.16 & 0.013 & $0.270 * * *$ & 2.90 & 0.009 & $-0.352 * * *$ & -3.94 & -0.012 \\
\hline Luxembourg & $0.211^{* *}$ & 2.10 & 0.016 & 0.099 & 1.01 & 0.008 & -0.106 & -1.18 & -0.008 \\
\hline Malta & 0.193 & 1.22 & 0.011 & -0.053 & -0.37 & -0.003 & -0.014 & -0.11 & -0.001 \\
\hline Netherlands & 0.117 & 0.90 & 0.007 & $0.240 *$ & 1.84 & 0.013 & 0.154 & 1.06 & 0.009 \\
\hline North Ireland & $1.513^{* *}$ & 2.34 & 0.000 & $0.576^{* * *}$ & 3.15 & 0.001 & -0.263 & -0.80 & 0.000 \\
\hline Portugal & 9.210 & 1.28 & 0.000 & -0.382 & -1.30 & 0.000 & 0.032 & 0.12 & 0.000 \\
\hline Spain & $1.141^{* * *}$ & 3.76 & 0.001 & $0.391 * * *$ & 3.01 & 0.004 & $-0.406^{* *}$ & -2.40 & -0.004 \\
\hline Sweden & $0.346^{* *}$ & 2.13 & 0.013 & 0.178 & 1.37 & 0.007 & -0.151 & -1.60 & -0.006 \\
\hline \multicolumn{10}{|l|}{$\begin{array}{l}\text { Eastern European } \\
\text { Countries }\end{array}$} \\
\hline Belarus & 0.118 & 1.27 & 0.003 & 0.060 & 0.63 & 0.001 & $0.178 * *$ & 2.04 & 0.005 \\
\hline Bulgaria & $0.479 * * *$ & 3.50 & 0.007 & $0.277 * *$ & 2.01 & 0.005 & -0.174 & -1.25 & -0.003 \\
\hline Croatia & 0.167 & 1.15 & 0.003 & -0.063 & -0.31 & -0.001 & -0.039 & -0.26 & -0.001 \\
\hline Czech Republic & 0.130 & 1.39 & 0.008 & $0.156^{*}$ & 1.72 & 0.009 & $-0.162 *$ & -1.77 & -0.009 \\
\hline Estonia & $0.746 * * *$ & 3.99 & 0.000 & 0.249 & 1.10 & 0.000 & -0.288 & -1.60 & 0.000 \\
\hline
\end{tabular}




\begin{tabular}{|l|lll|lll|ll|l|} 
Greece & $0.226^{* * *}$ & 2.72 & 0.035 & 0.111 & 1.64 & 0.018 & 0.049 & 0.74 & 0.008 \\
Hungary & $0.362 * * *$ & 3.42 & 0.011 & $0.211^{*}$ & 1.86 & 0.008 & -0.137 & -1.46 & -0.005 \\
Latvia & 0.009 & 0.06 & 0.000 & 0.008 & 0.07 & 0.000 & 0.226 & 0.23 & 0.001 \\
Lithuania & $0.886^{* * *}$ & 3.87 & 0.003 & $0.741^{* * *}$ & 3.55 & 0.006 & 0.009 & 0.03 & 0.000 \\
Poland & $1.010^{* * *}$ & 3.48 & 0.000 & 0.028 & 0.13 & 0.000 & $-0.367 * *$ & -2.40 & 0.000 \\
Romania & -0.127 & -0.73 & -0.001 & 0.076 & 0.50 & 0.001 & 0.318 & 1.12 & 0.003 \\
Russia & $0.337 * * *$ & 2.80 & 0.003 & $0.309 *$ & 1.85 & 0.004 & 0.189 & 1.19 & 0.003 \\
Slovak Republic & $0.358^{* * *}$ & 2.63 & 0.013 & $0.341^{* * *}$ & 3.08 & 0.013 & $-0.197 * *$ & -2.29 & -0.009 \\
Slovenia & 0.126 & 0.71 & 0.008 & 0.016 & 0.12 & 0.001 & 0.007 & 0.07 & 0.070 \\
Ukraine & 0.175 & 0.62 & 0.000 & $0.586^{* * *}$ & 2.84 & 0.000 & $-1.183^{* * *}$ & -4.74 & 0.000 \\
\hline
\end{tabular}

Notes: Only the attitudinal coefficient is reported in the Table. Regressions without the economic situation. The symbols $*, * *, * * *$ represent statistical significance at the $10 \%, 5 \%$ and $1 \%$ levels, respectively. Robust standard errors. 


\section{MACRO EXTENSION}

In a next step we are going to explore whether the previous results remain robust at the macro level. We therefore extend the number of countries to include those from the World Values Survey (see Appendix), and build averages out of the country values. However, we do not recode the original environmental motivation variables, which means that higher values are related to lower environmental motivation for the first two variables (willingness to give income and willingness to increase taxes). In other words, we measure the non-willingness to give income or increase taxes. We are going to use a simple OLS regression using the latest 2000 data.

We report beta or standardized regression coefficients to reveal the relative importance of the variables employed. To obtain robust standard errors in these estimations, we use the Huber/White/Sandwich estimators of standard errors. We are also providing the elasticity of $y$ with respect to $x$ equivalent to $\partial \log (y) / \partial \log (x)$ evaluated at the multivariate point of means of the data. As control variables we are going to use a proxy for institutional quality, the growth rate, the level of urbanization and the population size AGE $>65$. Institutional quality has been measured using the POLITICAL RISK RATING from the International Country Risk Guide. It is an index that measures government stability, internal and external conflicts, corruption, law and order, democratic accountability, bureaucracy quality, ethnic and religious tensions, the military in politics and the socioeconomic and investment conditions. Higher values are correlated with better institutions. We also control for the level of economic development and urbanization. A higher level of urbanization may provide 
a larger potential subject pool, but on the other hand it also increases the level of anonymity among individuals. It could be argued that this higher degree of anonymity would lead to higher transaction costs when forming a voluntary organization. We control for the age structure (in line with the micro analysis), as it is expected that the number of individuals who are actively involved in environmental organizations decreases as age increases. The intuition is that older people will not live to enjoy the benefits of preserving resources for later years. However, it can be argued that as people age, they become more cautious, more risk averse and more conservative or compliant (Torgler 2007), and they have more free time, so the correlation can also be positive. Table 8 presents the results using both dependent variables. We again observe that environmental motivation is correlated with environmental participation, which is in line with the results of the micro level analysis. The coefficients for the two first proxies are always statistically significant, reporting relatively large beta coefficients next to the political factors. Similarly, the calculated elasticities demonstrate that these two environmental motivation regressors are elastic, with a decrease in environmental motivation having more than four times as large an effect on environmental participation. However it should be noted that the coefficient on the third proxy is not statistically significant.

Looking at the control variables we observe that there is a positive relationship between institutional/governance quality proxied by POLITICAL RISK FACTOR and participation in environmental organizations.. However, the factor is more relevant when analyzing membership participation. Looking at the other variables we observe a negative relationship between urbanization and environmental participation, yet the coefficient is only statistically significant when focusing on unpaid work. 
Moreover, the variables on economic growth and population structure are hardly statistically significant ${ }^{8}$.

Table 8: Macro Evidence

\begin{tabular}{|c|c|c|c|c|c|c|}
\hline \multirow{3}{*}{\begin{tabular}{|l|} 
Dep Variable \\
Environmental Motivation \\
NON-WILLINGNESS TO GIVE INCOME
\end{tabular}} & \multicolumn{3}{|c|}{ Membership } & \multicolumn{3}{|c|}{ Unpaid Work } \\
\hline & \multirow{4}{*}{\multicolumn{3}{|c|}{$\begin{array}{l}-0.392 * * * \\
-2.96 \\
-4.130\end{array}$}} & \multirow{4}{*}{\multicolumn{3}{|c|}{$\begin{array}{l}-0.236^{*} \\
-\mathbf{1 . 8 4} \\
-2.657\end{array}$}} \\
\hline & & & & & & \\
\hline & & & & & & \\
\hline & & & & & & \\
\hline \multirow[t]{3}{*}{ NON-WILLINGNESS TO INCREASE TAXES } & \multicolumn{3}{|c|}{$-0.406^{* * *}$} & \multicolumn{3}{|c|}{$-0.369 * * *$} \\
\hline & \multirow{2}{*}{\multicolumn{3}{|c|}{$\begin{array}{l}-4.25 \\
-5.080\end{array}$}} & \multicolumn{3}{|c|}{-3.16} \\
\hline & & & & & -4.950 & \\
\hline \multirow[t]{3}{*}{ AGAINST CONTRIBUTE AT NO COSTS } & & & 0.258 & & & 0.058 \\
\hline & & & 0.93 & & & 0.27 \\
\hline & & & 2.069 & & & 0.498 \\
\hline \multicolumn{7}{|l|}{ Political Factor } \\
\hline \multirow[t]{3}{*}{ POLITICAL RISK FACTOR } & $0.562 * *$ & $0.501 *$ & $0.410 *$ & $0.228 *$ & 0.163 & 0.204 \\
\hline & 2.00 & 1.78 & 1.76 & 1.83 & 1.40 & 1.00 \\
\hline & 4.160 & 3.709 & 3.037 & 1.805 & 1.295 & 1.621 \\
\hline \multicolumn{7}{|l|}{ Further Factors } \\
\hline \multirow[t]{3}{*}{ GDP GROWTH } & -0.111 & -0.142 & -0.050 & 0.155 & 0.112 & 0.188 \\
\hline & -0.82 & -1.08 & -0.37 & 1.05 & 0.82 & 1.16 \\
\hline & -0.198 & -0.253 & -0.089 & 0.297 & 0.214 & 0.358 \\
\hline \multirow[t]{3}{*}{ URBANIZATION } & -0.042 & -0.039 & -0.129 & -0.422 & $-0.390 *$ & $-0.478 * *$ \\
\hline & -0.21 & -0.21 & -0.61 & $-1.87 *$ & -1.91 & -2.03 \\
\hline & -0.166 & -0.154 & -0.512 & -1.799 & -1.662 & -2.035 \\
\hline \multirow[t]{3}{*}{ POPULATION (AGE > 65) } & $-0.481^{*}$ & -0.462 & -0.425 & -0.107 & -0.071 & -0.119 \\
\hline & -1.67 & -1.57 & -1.46 & -0.48 & -0.32 & -0.39 \\
\hline & -1.436 & -1.381 & -1.269 & -0.343 & -0.226 & -0.380 \\
\hline REGIONS & YES & YES & YES & YES & YES & YES \\
\hline Prob > F & 0.004 & 0.000 & 0.024 & 0.056 & 0.010 & 0.074 \\
\hline $\mathrm{R}^{2}$ & 0.369 & 0.375 & 0.302 & 0.456 & 0.513 & 0.418 \\
\hline \# of observations & 52 & 52 & 52 & 52 & 52 & 52 \\
\hline
\end{tabular}

Notes: Robust standard errors. Beta/standardized coefficients reported. t-values in bold and elasticities in italics. The symbols *, **, *** represent statistical significance at the $10 \%, 5 \%$ and $1 \%$ levels, respectively. Regions: Dummies using the common differentiation (Europe, Latin America, North America, North Africa, Sub Saharan Africa, the Pacific, Asia, the Caribbean and Australia).

${ }^{8}$ It should be noted that the impact of economic growth does not when neglecting the political institutions in the regressions. 
Table 9: 2SLS Focusing on Membership Participation

\begin{tabular}{|c|c|c|c|c|c|c|}
\hline \multirow[t]{2}{*}{ Dep. Variable: Membership } & \multirow[b]{2}{*}{$\begin{array}{l}\text { IV } \\
\text { (2SLS) } \\
\text { estimation }\end{array}$} & \multirow[b]{2}{*}{$\begin{array}{l}\text { First Stage } \\
\text { Regression }\end{array}$} & \multirow[b]{2}{*}{$\begin{array}{l}\text { IV } \\
\text { (2SLS) } \\
\text { estimation }\end{array}$} & \multirow[b]{2}{*}{$\begin{array}{l}\text { First Stage } \\
\text { Regression }\end{array}$} & \multirow[b]{2}{*}{$\begin{array}{l}\text { IV (2SLS) } \\
\text { estimation }\end{array}$} & \multirow[b]{2}{*}{$\begin{array}{l}\text { First } \\
\text { Stage } \\
\text { Regression }\end{array}$} \\
\hline & & & & & & \\
\hline $\begin{array}{l}\text { Environmental Motivation } \\
\text { NON-WILLINGNESS TO GIVE INCOME }\end{array}$ & $\begin{array}{l}-0.310^{*} \\
-1.95\end{array}$ & & & & & \\
\hline $\begin{array}{l}\text { NON-WILLINGNESS TO INCREASE } \\
\text { TAXES }\end{array}$ & & & $\begin{array}{l}-0.262^{* *} \\
-2.17\end{array}$ & & & \\
\hline AGAINST CONTRIBUTE AT NO COSTS & & & & & $\begin{array}{l}0.280^{*} \\
1.67\end{array}$ & \\
\hline Political Factor & & & & & & \\
\hline POLITICAL RISK FACTOR & $\begin{array}{l}0.003^{* *} \\
2.15\end{array}$ & $\begin{array}{l}0.0003 \\
0.08\end{array}$ & $\begin{array}{l}0.002 * \\
1.81\end{array}$ & $\begin{array}{l}-0.001 \\
-0.38\end{array}$ & $\begin{array}{l}-0.002 \\
-0.45\end{array}$ & $\begin{array}{l}0.015 \\
2.92\end{array}$ \\
\hline Further Factors & & & & & & \\
\hline GDP GROWTH & $\begin{array}{l}-0.005 \\
-1.15\end{array}$ & $\begin{array}{l}-0.014 \\
-1.00\end{array}$ & $\begin{array}{l}-0.006 \\
-1.38\end{array}$ & $\begin{array}{l}-0.019 \\
-1.47\end{array}$ & $\begin{array}{l}-0.0002 \\
-0.03\end{array}$ & $\begin{array}{l}-0.003 \\
-0.19\end{array}$ \\
\hline URBANIZATION & $\begin{array}{l}0.0003 \\
0.33\end{array}$ & $\begin{array}{l}0.004 \\
1.36\end{array}$ & $\begin{array}{l}0.0002 \\
0.24\end{array}$ & $\begin{array}{l}0.004 \\
1.60\end{array}$ & $\begin{array}{l}-0.0004 \\
-0.37\end{array}$ & $\begin{array}{l}-0.002 \\
-0.56\end{array}$ \\
\hline POPULATION (AGE > 65) & $\begin{array}{l}-0.004 \\
-0.81\end{array}$ & $\begin{array}{l}0.007 \\
0.43\end{array}$ & $\begin{array}{l}-0.005 \\
-1.14\end{array}$ & $\begin{array}{l}0.005 \\
0.31\end{array}$ & $\begin{array}{l}0.0003 \\
0.03\end{array}$ & $\begin{array}{l}-0.023 \\
-1.24\end{array}$ \\
\hline REGIONS & YES & YES & YES & YES & YES & YES \\
\hline Instrument: & & & & & & \\
\hline CHILD QUALITIES: TOLERANCE & & $-0.836^{*}$ & & $-0.990 * *$ & & $0.924 *$ \\
\hline AND RESPECT FOR OTHER PEOPLE & & -1.92 & & -2.47 & & 1.78 \\
\hline $\begin{array}{l}\text { Test of excluded } \\
\text { instruments } \\
\text { Identification/IV relevance test: }\end{array}$ & & $3.67 *$ & & $6.09 * *$ & & $3.16^{*}$ \\
\hline $\begin{array}{l}\text { Anderson canon. corr. LR statistic } \\
\text { Weak identification statistics: }\end{array}$ & $4.479 * *$ & & $7.232 * * *$ & & $3.881^{* *}$ & \\
\hline Anderson-Rubin test & $4.26^{* *}$ & & $4.26^{* *}$ & & $4.26^{* *}$ & \\
\hline
\end{tabular}

Notes: t-values in italics. The symbols *, **, *** represent statistical significance at the $10 \%, 5 \%$ and $1 \%$ levels, respectively. Regions: Dummies using the common differentiation (Europe, Latin America, North America, North Africa, Sub Saharan Africa, the Pacific, Asia, the Caribbean and Australia). 
Table 10: 2SLS Focusing on Unpaid Work

\begin{tabular}{|c|c|c|c|c|c|c|}
\hline \multirow[t]{2}{*}{ Dep. Variable: Unpaid Work } & \multirow[b]{2}{*}{$\begin{array}{l}\text { IV } \\
\text { (2SLS) } \\
\text { estimation }\end{array}$} & \multirow[b]{2}{*}{$\begin{array}{l}\text { First Stage } \\
\text { Regression }\end{array}$} & \multirow[b]{2}{*}{$\begin{array}{l}\text { IV } \\
\text { (2SLS) } \\
\text { estimation }\end{array}$} & \multirow[b]{2}{*}{$\begin{array}{l}\text { First Stage } \\
\text { Regression }\end{array}$} & \multirow[b]{2}{*}{$\begin{array}{l}\text { IV (2SLS) } \\
\text { estimation }\end{array}$} & \multirow[b]{2}{*}{$\begin{array}{l}\text { First } \\
\text { Stage } \\
\text { Regression }\end{array}$} \\
\hline & & & & & & \\
\hline $\begin{array}{l}\text { Environmental Motivation } \\
\text { NON-WILLINGNESS TO GIVE INCOME }\end{array}$ & $\begin{array}{l}-0.187^{*} \\
-1.73\end{array}$ & & & & & \\
\hline $\begin{array}{l}\text { NON-WILLINGNESS TO INCREASE } \\
\text { TAXES }\end{array}$ & & & $\begin{array}{l}-0.158^{* *} \\
-2.11\end{array}$ & & & \\
\hline AGAINST CONTRIBUTE AT NO COSTS & & & & & $\begin{array}{l}0.169 \\
1.46\end{array}$ & \\
\hline Political Factor & & & & & & \\
\hline POLITICAL RISK FACTOR & $\begin{array}{l}0.001 \\
0.64\end{array}$ & $\begin{array}{l}0.0003 \\
0.08\end{array}$ & $\begin{array}{l}0.0003 \\
0.34\end{array}$ & $\begin{array}{l}-0.001 \\
-0.38\end{array}$ & $\begin{array}{l}-0.002 \\
-0.87\end{array}$ & $\begin{array}{l}0.015^{* * *} \\
2.92\end{array}$ \\
\hline Further Factors & & & & & & \\
\hline GDP GROWTH & $\begin{array}{l}0.001 \\
0.30\end{array}$ & $\begin{array}{l}-0.014 \\
-1.00\end{array}$ & $\begin{array}{l}0.001 \\
0.22\end{array}$ & $\begin{array}{l}-0.019 \\
-1.47\end{array}$ & $\begin{array}{l}0.004 \\
1.19\end{array}$ & $\begin{array}{l}-0.003 \\
-0.19\end{array}$ \\
\hline URBANIZATION & $\begin{array}{l}-0.001 \\
-1.26\end{array}$ & $\begin{array}{l}0.004 \\
1.36\end{array}$ & $\begin{array}{l}-0.001^{*} \\
-1.70\end{array}$ & $\begin{array}{l}0.004 \\
1.60\end{array}$ & $\begin{array}{l}-0.001^{*} \\
-1.77\end{array}$ & $\begin{array}{l}-0.002 \\
-0.56\end{array}$ \\
\hline POPULATION (AGE > 65) & $\begin{array}{l}0.001 \\
0.29\end{array}$ & $\begin{array}{l}0.007 \\
0.43\end{array}$ & $\begin{array}{l}0.0005 \\
0.18\end{array}$ & $\begin{array}{l}0.005 \\
0.31\end{array}$ & $\begin{array}{l}0.004 \\
0.71\end{array}$ & $\begin{array}{l}-0.023 \\
-1.24\end{array}$ \\
\hline REGIONS & YES & YES & YES & YES & YES & YES \\
\hline Instrument: & & & & & & \\
\hline CHILD QUALITIES: TOLERANCE & & $-0.836^{*}$ & & $-0.990 * *$ & & $0.924 *$ \\
\hline AND RESPECT FOR OTHER PEOPLE & & -1.92 & & -2.47 & & 1.78 \\
\hline $\begin{array}{l}\text { Test of excluded } \\
\text { instruments } \\
\text { Identification/IV relevance test: }\end{array}$ & & $3.67^{*}$ & & $6.09 * *$ & & $3.16^{*}$ \\
\hline $\begin{array}{l}\text { Anderson canon. corr. LR statistic } \\
\text { Weak identification statistics: }\end{array}$ & $4.479 * *$ & & $7.232 * * *$ & & $3.881^{* *}$ & \\
\hline Anderson-Rubin test & $3.71 *$ & & $3.71^{*}$ & & $3.71^{*}$ & \\
\hline
\end{tabular}

Notes: t-values in italics. The symbols *,**, *** represent statistical significance at the $10 \%, 5 \%$ and $1 \%$ levels, respectively. Regions: Dummies using the common differentiation (Europe, Latin America, North America, North Africa, Sub Saharan Africa, the Pacific, Asia, the Caribbean and Australia).

In line with the micro estimations we also present 2SLS regressions. It should be noted that we are not able to use the previous instrument as it would substantially reduce the number of observations. We therefore use an alternative instrument, namely CHILD QUALITIES: TOLERANCE AND RESPECT FOR OTHER 
PEOPLE $^{9}$. It measures the individuals' willingness to educate their children on social norms. Thus, we would predict a statistically significant correlation between our environmental motivational variables and such a variable. Additionally, tolerance and other related attitudes are features of affective education clearly linked to cooperation and interaction among people lead which generate children's abilities related to social capital issues (Nixon et al, 1996). This relationship is confirmed when looking at the first stage regressions in Table 9 and 10. We also conduct the Anderson's likelihoodratio test. A failure to reject the null hypothesis would call the identification status of the estimated equation into question. Table 9 and 10 show that we can reject the null hypothesis that our specified instrument is redundant. In general, the results obtained in the six 2SLS estimations indicate that our previous findings on the key hypothesis remain robust. We observe a relatively robust relationship between environmental motivation and environmental participation.

\section{CONCLUSIONS}

This paper investigates whether environmental motivation affects environmental behavior. We therefore first present a model that explores the relationship between environmental motivation and volunteering, and then test empirically the hypothesis generated by that theoretical model. Behavioral engagement was proxied through the reported participation in environmental organizations. We focused on two aspects of participation, namely being a member and doing unpaid work for environmental organizations. We also use three different proxies for environmental motivation, two

${ }^{9}$ Question: Here is a list of qualities that children can be encouraged to learn at home. Which, if any, do you consider to be especially important? Please choose up to five. (CODE FIVE ONLY). Tolerance and respect for other people $(0=$ Not mentioned, $1=$ Important $)$. 
of which measure pro-environmental attitudes, namely the willingness to give part of the own income to prevent environmental pollution, and whether the respondent would agree to an increase in taxes if the extra money is used to prevent environmental pollution. In addition, we have explored a variable that measures people's incentive to free-ride (profit without incurring costs). The motivation behind such a study is the observation that deterrence models fail to predict the relatively high level of compliance in various situations where a private cost is incurred in order to provide a public good. Previous literature on this paradox covers situations such as tax compliance despite the low chance of being audited and not littering despite the low probability of getting caught and penalized. This paper provides empirical support for the idea that environmental motivation indeed affects individuals' voluntary involvement in environmental organizations. By using a large micro-data set covering not less than 32 different countries we are able to provide a comprehensive summary for every single country (almost 200 regressions). In addition, we check the robustness of the results using a macro approach, and here we extend the number of countries by including data from the World Values Survey. In addition, we have explored potential endogeneity problems. The results show robust findings and therefore indicate that attitudinal questions help to explain behavioral consequences. Environmental motivation, environmental morale or pro-environmental attitudes are highly relevant to an understanding of why people have a higher willingness to be involved in environmental protection. However, it should be noted that these social norms work more strongly towards membership of an environmental organization rather than doing unpaid work in these groups. Unpaid work is associated with higher opportunity costs which may help to explain such a difference. 
The results of our analyses present an insight into voluntary participation and whose preferences are being served by voluntary provision of a public environmental good. Considering the difficulty and expense involved in regulating to protect the environment, (and the political sensitivity of such actions), policymakers seeking the most effective ways to address the consequences of climate change and ecological degradation could find efficient solutions through crowding-in these motivations.

These empirical findings are not only useful in the context of environmental issues, but can also be applied to voluntary participation and provision of public goods more generally. Ostrom $(2000,154)$ claims that the (pre-Mancur Olson) idea of collective action arising organically from groups in order to solve their own dilemmas was "not entirely misguided", and maintains that institutional, cultural and biophysical contexts may play a role in determining which individuals join collective action groups. Ostrom also raises the uncomfortable point that past policy based on payoff structures appealing to the rational egoists could have been misdirected. In fact, this could have worked against the original intention of the policy, crowding out social norms that encourage cooperative behavior rather than encouraging collective action (Ostrom 2000, 154).

With respect to environmental issues, by focusing on willingness to pay for environmental quality, past policy may have placed an inappropriate emphasis on financial values for the environment. Moreover, as pro-social behavior is both voluntary and conditioned by observed norms of behavior in society, there exists a stronger chance to crowd in these behaviors than to persist in seeking the appropriate monetary value for the environment based on an individually stated willingness to incur private costs in order to supply a public good. In seeking policy implications from the current study, we could look to policies supporting formation of new 
community based organizations and partnerships with existing organizations. A partnership that matches community effort could increase the warm glow ' $g$ ' for the purely egoistic contributor while also increasing the ' $G$ ' for the purely altruistic contributor. If policies cease to be aimed at the rational egoist and instead are aimed at crowding in existing motivations and pro-social behaviors, environmental quality may be ensured at lower transaction and policing costs. Finally, it should be noted that further investigations are required to gain a better understanding of what shapes individuals' environmental motivation. This would provide a better foundation to derive policy implications to promote, encourage and maintain a higher willingness to contribute to the environment. 
Table A1:

Description of control variables

\begin{tabular}{|c|c|}
\hline Variable & Definitions \\
\hline \multicolumn{2}{|l|}{ Micro Analysis } \\
\hline AGE & $\begin{array}{l}\text { AGE 30-39, AGE40-49, AGE 50-59, AGE 60-69, AGE +70 (AGE -30 in the } \\
\text { reference group,) }\end{array}$ \\
\hline GENDER & WOMAN (MAN in the reference group) \\
\hline PARENT EFFECT & CHILD (not having children in the reference group) \\
\hline \multirow[t]{2}{*}{$\begin{array}{l}\text { FORMAL AND INFORMAL } \\
\text { EDUCATION }\end{array}$} & $\begin{array}{l}\text { EDUCATION: } \\
\text { What is the highest educational level that you have attained? } \\
\text { 1. No formal education } \\
\text { 2. Incomplete primary school } \\
\text { 3. Completed primary school } \\
\text { 4. Incomplete secondary school: technical/vocational type } \\
\text { 5. Complete secondary school: technical/vocational type } \\
\text { 6. Incomplete secondary: university-preparatory type } \\
\text { 7. Complete secondary: university-preparatory type } \\
\text { 8. } \\
\text { 9. } \\
\text { Some university-level education, without degree } \\
\end{array}$ \\
\hline & $\begin{array}{l}\text { POLITICAL DISCUSSION: } \\
\text { When you get together with your friends, would you say you discuss political } \\
\text { matters? } \\
\text { 1. Never } \\
\text { 2. Occasionally } \\
\text { 3. Frequently }\end{array}$ \\
\hline MARITAL STATUS & $\begin{array}{l}\text { WIDOWED; DIVORCED; SEPARATED; NEVER MARRIED (MARRIED in } \\
\text { the reference group) }\end{array}$ \\
\hline ECONOMIC SITUATION & $\begin{array}{l}\text { People sometimes describe themselves as belonging to the working class, the } \\
\text { middle class, or the upper or lower class. Would you describe yourself as } \\
\text { belonging to the: } \\
\text { UPPER CLASS, MIDDLE CLASS (the rest, WORKING CLASS and LOWER } \\
\text { CLASS, in the reference group). }\end{array}$ \\
\hline EMPLOYMENT STATUS & $\begin{array}{l}\text { PART-TIME EMPLOYEE, SELFEMPLOYED, UNEMPLOYED, AT HOME, } \\
\text { STUDENT, RETIRED, OTHER (FULL TIME EMPLOYED in the reference } \\
\text { group). }\end{array}$ \\
\hline \multicolumn{2}{|l|}{ Macro Analysis } \\
\hline POLITICAL RISK FACTOR & $\begin{array}{l}\text { ICRG index covering } 12 \text { factors (government stability, socioeconomic } \\
\text { conditions, investment profile, internal conflict, external conflict, corruption, } \\
\text { military in politics, religious tension, law and order, ethnic tensions, democratic } \\
\text { accountability, and bureaucracy). For a detailed description see: } \\
\text { http://www.icrgonline.com/page.aspx?page=icrgmethods\#Background_of the_I } \\
\text { CRG_Rating_System. }\end{array}$ \\
\hline GDP GROWTH & GDP per capita growth (annual \%). Source: World Development Indicators. \\
\hline URBANIZATION & Urban population (\% of total). Source: World Development Indicators. \\
\hline POPULATION (AGE > 65) & $\begin{array}{l}\text { Population ages } 65 \text { and above (\% of total). Source: World Development } \\
\text { Indicators. }\end{array}$ \\
\hline
\end{tabular}


Table A2: Descriptive Statistics Micro Analysis

\begin{tabular}{|c|c|c|c|c|c|}
\hline Variables & Obs & Mean & Std. Dev. & Min & Max \\
\hline \multicolumn{6}{|l|}{ Key variables } \\
\hline ENVIRONMENTAL ATTITUDES (INCOME) & 38877 & 1.620 & 0.885 & 0 & 3 \\
\hline ENVIRONMENTAL ATTIDUES (TAXES) & 38834 & 1.412 & 0.877 & 0 & 3 \\
\hline ENVIRONMENTAL FREE-RIDING & 39038 & 1.996 & 0.894 & 0 & 3 \\
\hline $\begin{array}{l}\text { ENVIRONMENTAL ORGANIZATION } \\
\text { WORKING VOLUNTARY }\end{array}$ & 41125 & 0.049 & 0.216 & 0 & 1 \\
\hline ENVIRONMENTAL ORGANIZATION & 41125 & 0.020 & 0.140 & 0 & 1 \\
\hline \multicolumn{6}{|l|}{ Control Variables } \\
\hline AGE 30-39 & 40963 & 0.197 & 0.398 & 0 & 1 \\
\hline AGE 40-49 & 40963 & 0.191 & 0.393 & 0 & 1 \\
\hline AGE 50-59 & 40963 & 0.15 & 0.357 & 0 & 1 \\
\hline AGE 60-69 & 40963 & 0.135 & 0.342 & 0 & 1 \\
\hline AGE 70+ & 40963 & 0.102 & 0.302 & 0 & 1 \\
\hline WOMAN & 41114 & 0.54 & 0.498 & 0 & 1 \\
\hline CHILDREN & 41125 & 0.077 & 0.266 & 0 & 1 \\
\hline EDUCATION & 39840 & 18.712 & 5.125 & 5 & 74 \\
\hline POLITICAL DISCUSSION & 40713 & 1.886 & 0.654 & 1 & 3 \\
\hline UPPER CLASS & 21335 & 0.136 & 0.343 & 0 & 1 \\
\hline MIDDLE CLASS & 21335 & 0.338 & 0.473 & 0 & 1 \\
\hline WIDOWED & 39861 & 0.097 & 0.295 & 0 & 1 \\
\hline DIVORCED & 39861 & 0.07 & 0.256 & 0 & 1 \\
\hline SEPARATED & 39861 & 0.016 & 0.124 & 0 & 1 \\
\hline NEVER MARRIED & 39861 & 0.228 & 0.42 & 0 & 1 \\
\hline PART TIME EMPLOYED & 40919 & 0.068 & 0.252 & 0 & 1 \\
\hline SELFEMPLOYED & 40919 & 0.052 & 0.222 & 0 & 1 \\
\hline UNEMPLOYED & 40919 & 0.229 & 0.42 & 0 & 1 \\
\hline AT HOME & 40919 & 0.095 & 0.293 & 0 & 1 \\
\hline STUDENT & 40919 & 0.061 & 0.24 & 0 & 1 \\
\hline RETIRED & 40919 & 0.073 & 0.261 & 0 & 1 \\
\hline OTHER & 40919 & 0.018 & 0.131 & 0 & 1 \\
\hline \multicolumn{6}{|l|}{ Instrument } \\
\hline PERCEIVED LEVEL OF DISHONESTY & 32903 & 13.098 & 2.496 & 5 & 20 \\
\hline
\end{tabular}


Table A3: Countries Macro Analysis

\begin{tabular}{|ll|}
\hline ALBANIA & LITHUANIA \\
ARGENTINA & LUXEMBOURG \\
AUSTRIA & MALTA \\
BANGLADESH & MEXICO \\
BELARUS & MOLDOVA \\
BELGIUM & NETHERLANDS \\
BULGARIA & PERU \\
CANADA & PHILIPPINES \\
CHILE & POLAND \\
CHINA & PORTUGAL \\
CROATIA & ROMANIA \\
CZECH REPUBLIC & RUSSIA \\
DENMARK & SINGAPORE \\
ESTONIA & SLOVAKIA \\
FINLAND & SLOVENIA \\
FRANCE & SOUTH AFRICA \\
GERMANY & SPAIN \\
GREECE & SWEDEN \\
HUNGARY & TANZANIA \\
ICELAND & TURKEY \\
INDIA & UGANDA \\
IRELAND & UKRAINE \\
ITALY & UNITED KINGDOM \\
JAPAN & UNITED STATES \\
SOUTH KOREA & VIETNAM \\
LATVIA & ZIMBABWE \\
\hline & \\
\hline
\end{tabular}

Table A4: Descriptive Statistics Macro Analysis

\begin{tabular}{|c|c|c|c|c|c|}
\hline & Obs & Mean & Std. Dev. & Min. & Max. \\
\hline MEMBERSHIP & 60 & 0.057 & 0.070 & 0.002 & 0.451 \\
\hline UNPAID WORK & 58 & 0.039 & 0.051 & 0.002 & 0.277 \\
\hline NON-WILLINGNESS TO GIVE INCOME & 57 & 2.248 & 0.270 & 1.583 & 3.052 \\
\hline NON-WILLINGNESS TO INCREASE TAXES & 57 & 2.039 & 0.307 & 1.380 & 2.806 \\
\hline AGAINST CONTRIBUTE AT NO COSTS & 57 & 2.472 & 0.253 & 1.866 & 3.135 \\
\hline POLITICAL RISK FACTOR & 140 & 66.383 & 13.970 & 31.083 & 95.250 \\
\hline GDP GROWTH & 186 & 2.507 & 4.396 & -16.580 & 18.940 \\
\hline URBANIZATION & 206 & 54.783 & 24.734 & 8.60 & 100 \\
\hline POPULATION (AGE > 65) & 188 & 6.888 & 4.581 & 1.08 & 18.21 \\
\hline $\begin{array}{l}\text { Instrument: } \\
\text { CHILD QUALITIES: TOLERANCE } \\
\text { AND RESPECT FOR OTHER PEOPLE }\end{array}$ & 68 & 0.705 & 0.0964 & 0.525 & 0.923 \\
\hline
\end{tabular}




\section{REFERENCES}

Adger, W.N., 2003. Social capital, collective action and adaptation to climate change. Economic Geography, 79, 387-404.

Ajzen, I. and Fishbein, M., 1980. Understanding attitudes and predicting social behaviour. London: Prentice Hall.

Andreoni, J., 1988. Privately provided public goods in a large economy: the limits of altruism. Journal of Public Economics, 35, 57-73.

Andreoni, J., 1990. Impure altruism and donations to public goods: A theory of warm-glow giving. Economic Journal, 100, 464-477.

Alm, J., Martinez-Vazquez, J. and Torgler, B., 2006. Russian attitudes toward paying taxes before, during, and after the transition. International Journal of Social Economics, 33, 832857.

Baldry, Jonathan C., 1987. Income tax evasion and the tax schedule: Some experimental results. Public Finance, 42, 357-383.

Brekke, K. A., Kverndokk, S. and Nyborg, K., 2003. An economic model of moral motivation. Journal of Public Economics, 87, 1967-1983.

Brewer, Paul R., Steenbergen, M.R. and Marco, R., 2002. All against all: How beliefs about human nature shape foreign policy opinions. Political Psychology, 23, 39-58.

Brewer, Paul R., Gross, Kimerly, Aday, Sean and Willnat, Lars, 2004. International trust and public opinion about world affairs. American Journal of Political Science, 48, 93-109.

Bulte, E., Gerking, S., List, J.A. and De Zeeuw, A., 2005. The effect of varying the causes of environmental problems on stated WTP values: evidence from a field study. Journal of Environmental Economics and Management, 49, 330-342.

Carson, R.T. and Mitchell, R.C., 1995. Sequencing and nesting in contingent valuation surveys. Journal of Environmental Economics and Management, 28, 155-173.

Chang, E.C.C. and Chu, Y., 2006. Corruption and trust: Exceptionalism in Asian democracies? Journal of Politics, 68, 259-271.

Clark, C.F., Kotchen, M.J. and Moore, M.R., 2003. Internal and external influences on proenvironmental behaviour: participation in a green electricity program. Journal of Environmental Psychology, 23, 237-246.

Davis, D.D. and Holt, C., 1993. Experimental Economics. Princeton: Princeton University Press. 
Dong, B., Dulleck, U. and Torgler, B., 2008. Conditional Corruption. CREMA Working Paper Series 2008-29, Center for Research in Economics, Management and the Arts (CREMA).

European Values, 1999. Questionnaire, The Netherlands: Tilburg University.

Freeman, R. B., 1997. Working for nothing: the supply of volunteer labor. Journal of Labor Economics, 15, S140-S.166.

Frey, B. S. and Stutzer, A. 2002. Happiness and Economics. Princeton: Princeton University Press.

Frey, B.S. and Stutzer, A., 2006. Environmental Morale and Motivation, CREMA Working Paper No. 2006-17, Basel.

Frey, B.S. and Torgler, B., 2007. Tax Morale and Conditional Cooperation. Journal of Comparative Economics., 35, 136-159.

Grootaert, C. and van Bastalaer, T., 2002. Understanding and measuring social capital : a multidisciplinary tool for practitioners.. Washington DC: World Bank.

Hackl, F., Halla, M. and Pruckner, G. J., 2007. Volunteering and income - The fallacy of the good samaritan? Kyklos, 60, 77-104.

Hall, A., Rudebusch, G. and Wilcox, D., 1996. Judging instrument relevance in instrumental variable estimation. International Economic Review, 37, 283-298.

Hidano, N., Kato, T. and Aritomi, M.., 2005. Benefits of participating in contingent valuation mail surveys and their effects on respondent behaviour: a panel analysis. Ecological Economics, 52, 63-80.

Jensen, B.B., 2002. Knowledge, action and pro-environmental behaviour. Environmental Educational Research, 8(3), 325-334.

Katz, E.G., 2000. Social capital and natural capital: a comparative analysis of land tenure and natural resource management in Guatemala. Land Economics, 76(1), 114-132.

Kollmuss, A. and Agyeman, J., 2002. Mind the gap: why do people act environmentally and what are the barriers to pro-environmental behaviour? Environmental Educational Research, 8(3), 239-260.

Ledyard, J. 1995. Public goods: A survey of experimental results. In: Kagel, John H., Roth, Alvin E. (Eds.), The Handbook of Experimental Economics. Princeton: Princeton University Press, pp. 111-194.

Lewis, A., 1982. The Psychology of Taxation. Oxford: Martin Robertson.

Lubell, M., Vedlitz, A., Zahran, S. And Alston, L.T. 2006. Collective action, environmental activism and air quality policy. Political Research Quarterly, 591, 149-160.

Martinez, T.A. and McMullin, S.L., 2004. Factors affecting decisions to volunteer in nongovernmental organizations. Environment \& Behaviour, 36, 112-126. 
Mohai, P., 1992. Men, women, and the environment: an examination of the gender gap in environmental concern and activism. Society and Natural Resources, 5, 1-19.

Nixon, J., Martín, J., McKeown, P. and Ranson, S., 1996. Encouraging Learning: Towards a theory of the learning school. Milton Keynes, Open University Press.

Ochs, J., Roth, A. E., 1989. An experimental study of sequential bargaining. American Economic Review, 79, 355-384.

Ostrom, E., 2000. Collective Action and the Evolution of Social Norms. The Journal of Economic Perspectives, 14, 137-158.

Owen, A.L. and Videras, J., 2006. Civic cooperation, pro-environmental attitudes, and behavioural intentions. Ecological Economics, 58, 814-829.

Paavola, J., and Adger, W. N., 2005. Institutional ecological economics, Ecological Economics, 53, 353-368.

Piliavin, J.A. and Charng, H., 1990. Altruism: a review of recent theory and research. Annual Review of Sociology, 16, 27-65.

Polinsky, M.A. and Shavell, S., 2000. The economic theory of public enforcement of law. Journal of Economic Literature, 38(1), 45-76.

Pretty, J. and Ward, H., 2001. Social capital and the environment. World Development, 29(2), 209-227.

Putnam, R. D., 1993. Making Democracy Work. Civic Traditions in Modern Italy, Princeton: Princeton University Press.

Roth, Alvin E., 1995. Bargaining experiments. In: Kagel, John H., Roth, Alvin E. (Eds.), The Handbook of Experimental Economics. Princeton: Princeton University Press, pp. 253-342.

Thompson, S.C.G. and Barton, M.A., 1994. Ecocentric and anthropocentric attitudes toward the environment. Journal of Environmental Psychology, 14, 149-157.

Torgler, B., 2003. Tax morale in transition countries. Post-Communist Economies, 15, 357381.

Torgler, B., 2007. Tax Compliance and Tax Morale: A Theoretical and Empirical Analysis, Cheltenham, UK: Edward Elgar.

Torgler, B. 2008. Trust in international organizations: an empirical investigation focusing on the United Nations, Review of International Organizations, 3, 65-93.

Torgler, B. and Garcia-Valiñas M. A., 2007. The determinants of individuals' attitudes towards preventing environmental damage. Ecological Economics, 62, 536-552.

Torgler, B., Frey B.S. and Wilson, C., 2007. Environmental and Pro-Social Norms: Evidence from 30 Countries, $\underline{\text { School of Economics and Finance Discussion Papers and Working Papers }}$ Series 220, School of Economics and Finance, Queensland University of Technology. 
Uslaner, E.M., 2004. Trust and corruption. In: Lambsdorf, Johann Graf, Taube, Markus and Schramm, Matthias (Eds.), Corruption and the New Institutional Economics. London: Routledge, pp. 76-92.

Witzke, H.P. and Urfei, G., 2001. Willingness to pay for environmental protection in Germany: coping with the regional dimension. Regional Studies, 35, 207-214. 